\title{
STARING WEI JIE TO DEATH (2017)
}

PARA ORCHESTRA

\section{Paulo do Nascimento Brito} (1987-)

E-mail: paulodnbrito@gmail.com

Tōru Takemitsu Composition Award: First Prize, 2018 


\section{Biography}

Paulo BritoisaBrazilian-Americancomposerand pianist. First-Prize Winner of the Toru Takemitsu Composition Award (Japan) - awarded by world-renowned composer Unsuk Chin, Brito has been featured at international venues including the Royaumont Festival's "Voix Nouvelles" Academy, Shanghai Conservatory New Music Week, and University of Toronto New Music Festival. His music has been performed by prominent artists including conductor Jean-Philippe Wurtz and the Ensemble Linéa (France), Japanese Noh singer Ryoko Aoki, conductor Yoichi Sugiyama and the Tokyo Philharmonic Orchestra.

Brito's music draws upon influences ranging from Western opera to East Asian music drama, reflecting his cross-cultural interest in multidisciplinary performance and in creating experimental, integrative pieces that dramatize the concert setting. Brito has studied with eminent composers including Toshio Hosokawa, Anthony Cheung and Christos Hatzis. Currently completing his doctorate at the University of Toronto, he previously studied comparative literature at the University of Chicago (M.A. 2016) and Classics at Columbia University (B.A. 2013). 


\section{Abstract}

Staring Wei Jie to Death uses the notion of evocation to give musical form to a peculiar story from ancient China. Wei Jie is a historical figure who served as a court official under the Jin dynasty during the late 3 rd to early 4 th centuries C.E. The Book of Jin relates that he was legendary even in his own time for his astonishing physical beauty, and that it proved to be the cause of his death. For when the Jin empire was threatened by barbarian invaders invaders, Wei Jie fled south, to the city known today as Nanjing; there, people were so eager to catch a glimpse of his unearthly beauty that a crowd gathered to see him arrive. But Wei Jie, frail in health, could not withstand the force of their collective gaze, and thus, the story goes, he was stared to death. Rather than narrating events in a linear or programmatic fashion, Staring Wei Jie to Death instead takes certain aural "cues" from the ancient text and calls upon the orchestra to evoke the textual narrative by giving sound to key elements associated with it. Each of the work's four sections is constructed around one of these elements, moving from sonically "concrete" to "abstract": the ringing of jade in "The Man of Jade" (jade being a Chinese metaphor for beauty), the din of battle in "Great Chaos under Heaven," the remote splendor of "Ancient Nanjing," and finally, the consuming power of the gaze in "Staring Wei Jie to Death." 


\title{
Paulo Brito
}
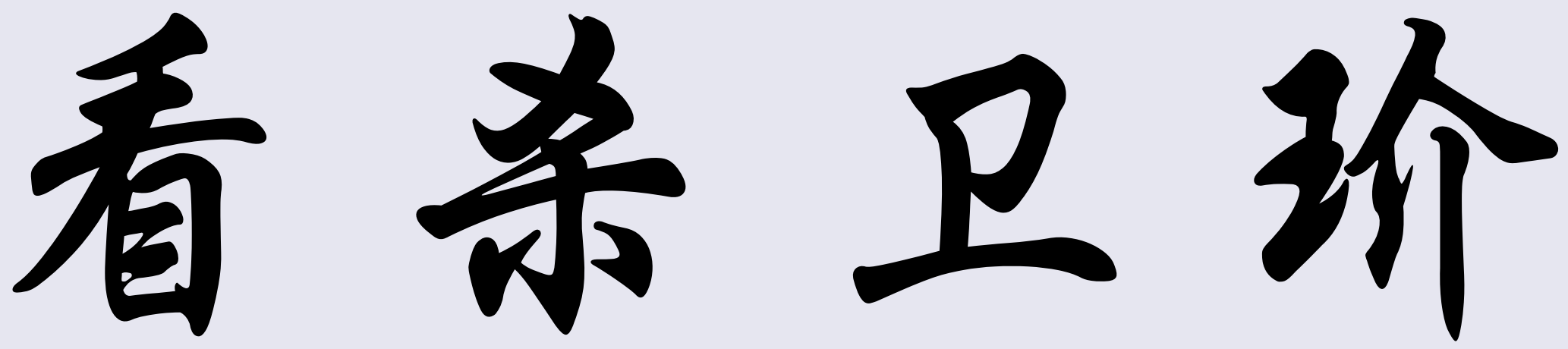

[Kan Sha Wei Jie]

\section{Staring Wei Jie to Death}

\author{
SympHONIC Evocation \\ Based on an Episode from Chinese Antiquity \\ FOR ORCHESTRA
}




\title{
Background
}

The story of Wei Jie (286-312 C.E.), though extant in several ancient Chinese sources, comes primarily from the Book of Jin, the annals of the Jin dynasty (265-410 C.E.). Wei Jie came from a prominent family of the ruling class, and himself served as an official at the imperial court. In his time, he was renowned for his oratory and rhetorical skill, but the source of his posthumous fame is rather different - his physical beauty, and the way it is supposed, according to the chronicle, to have caused his death. For while he was still a young man, China was thrown into turmoil by an invasion of barbarians. As the invaders moved in on the imperial capital, Wei Jie fled with his family southward, seeking the relative safety of the city known today as Nanjing. By the time he arrived there, word of his unearthly beauty had spread, so that all the townspeople had gathered to see him. Wei Jie, frail of health since childhood, did not have the strength to withstand the gaze of so many eyes upon him at once; thus, the legend goes, he was stared to death.

\section{Instrumentation}

2 Flutes $\left(2^{\text {nd }}\right.$ doubling piccolo)

2 Oboes $\left(2^{\text {nd }}\right.$ doubling cor anglais $)$

2 Clarinets ( $2^{\text {nd }}$ doubling bass clarinet)

2 Bassoons ( $2^{\text {nd }}$ doubling contrabassoon)

2 Horns

2 Trumpets in $\mathrm{C}$

2 Trombones

Timpani

Percussion -3 players:

- Triangle, Snare drum, Glockenspiel

- Tubular bells, Xylophone

- Bass drum, Vibraphone

\author{
Celesta \\ Harp \\ Piano \\ 8 First violins \\ 8 Second violins \\ 6 Violas \\ 4 Cellos \\ 2 Contrabasses
}

\section{Indications}

- The score is "in C": all instruments sound at the written pitch, except: piccolo, xylophone and celesta sound an octave higher, contrabassoon and contrabasses sound an octave lower (glockenspiel sounds two octaves higher).

- Accidentals are valid for a single pitch for the duration of the measure, and are maintained when tied over to the next measure (occasionally an accidental is repeated within the measure to avoid any ambiguity).

- The indication con sord. in the brass parts always means the straight mute.

- String sections always divide evenly (unless specifically indicated otherwise).

- Four-string contrabasses with a C-extension capable of tuning the open fourth string to the pitches between the low $\mathrm{C}$ and $\mathrm{E}$ are required.

- The four movements of the work are to be played continuously.

- Total performance time is approximately 10 minutes. 
I

\section{The Man of JADE}

Etereo tintinnante $d=60$
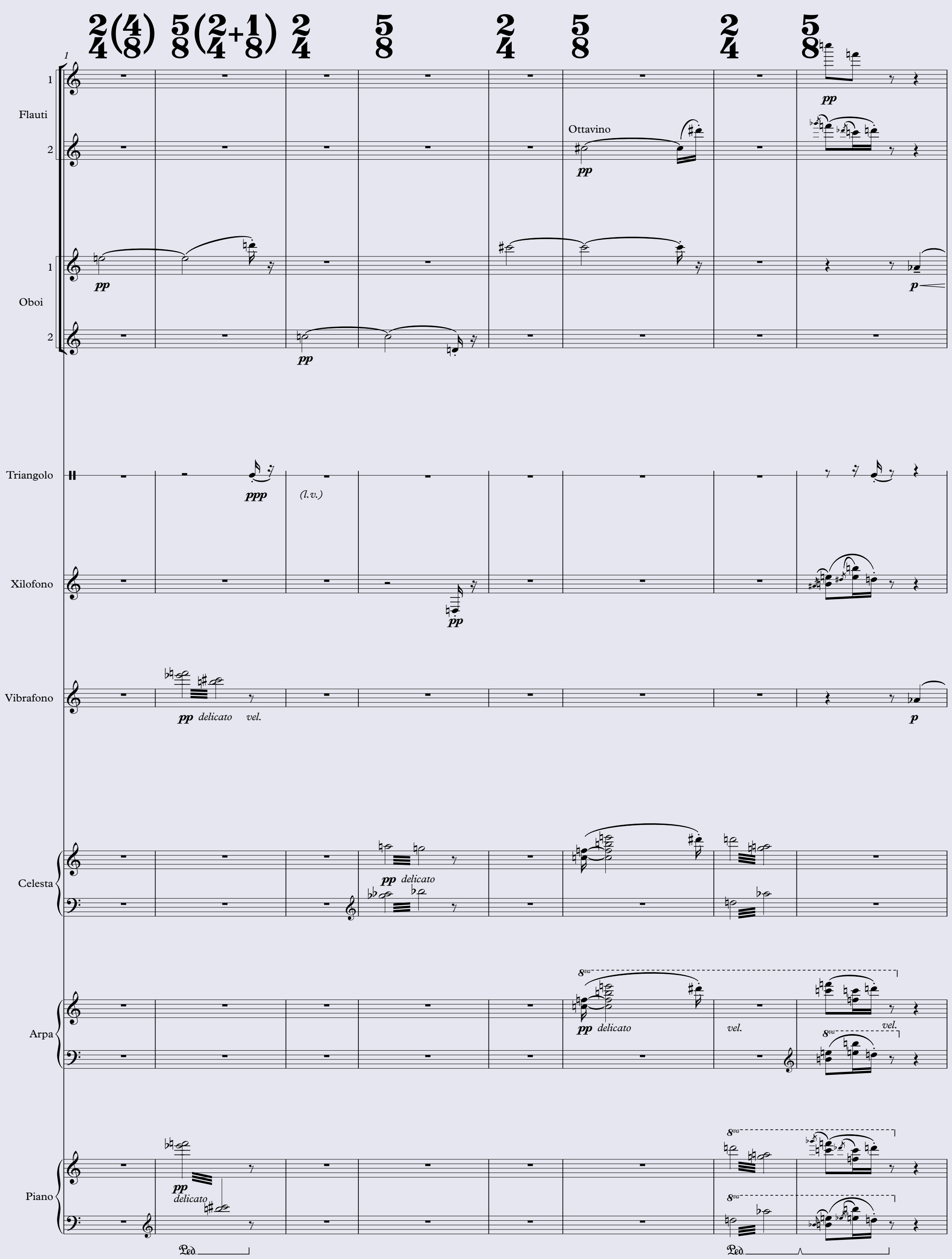

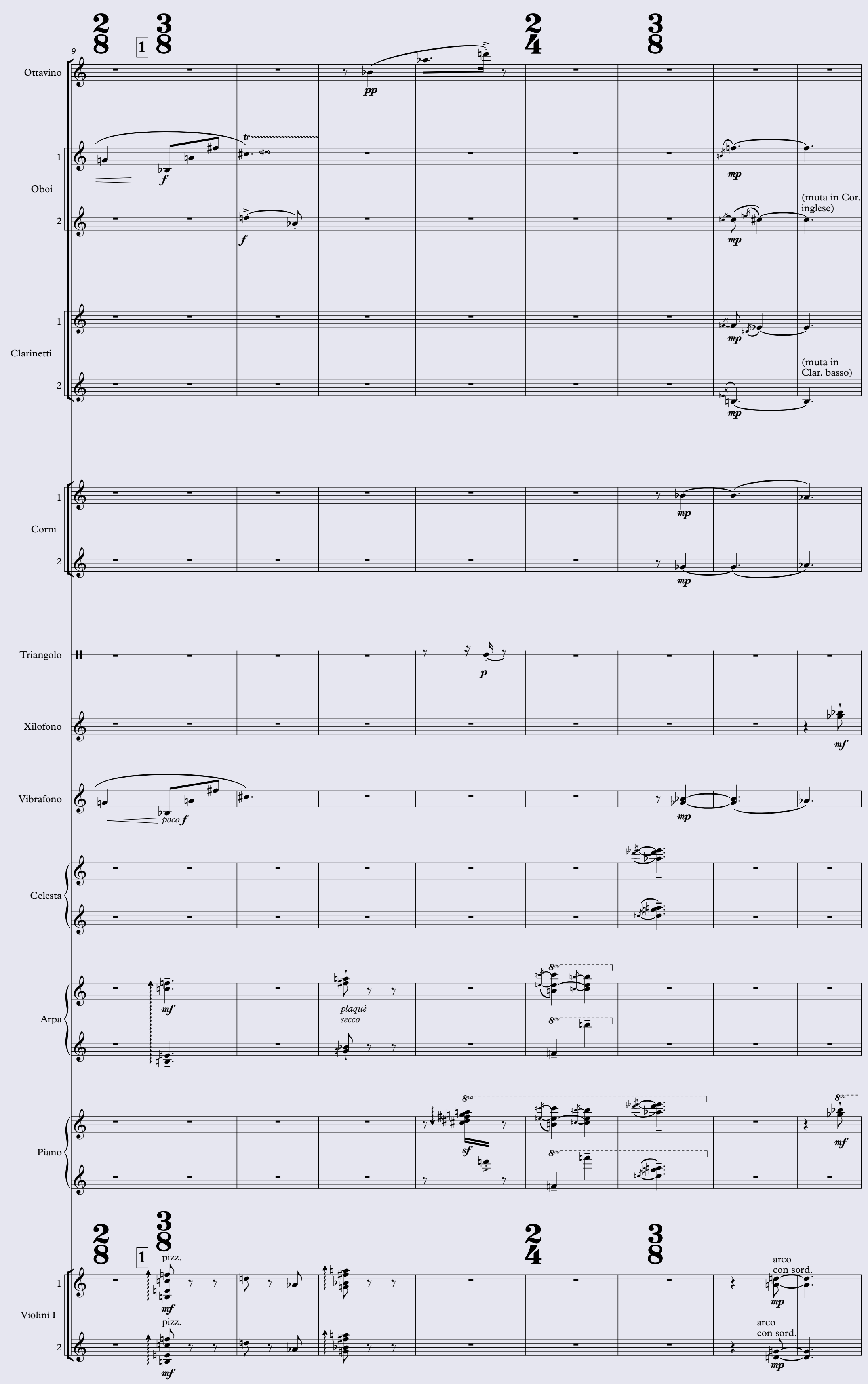

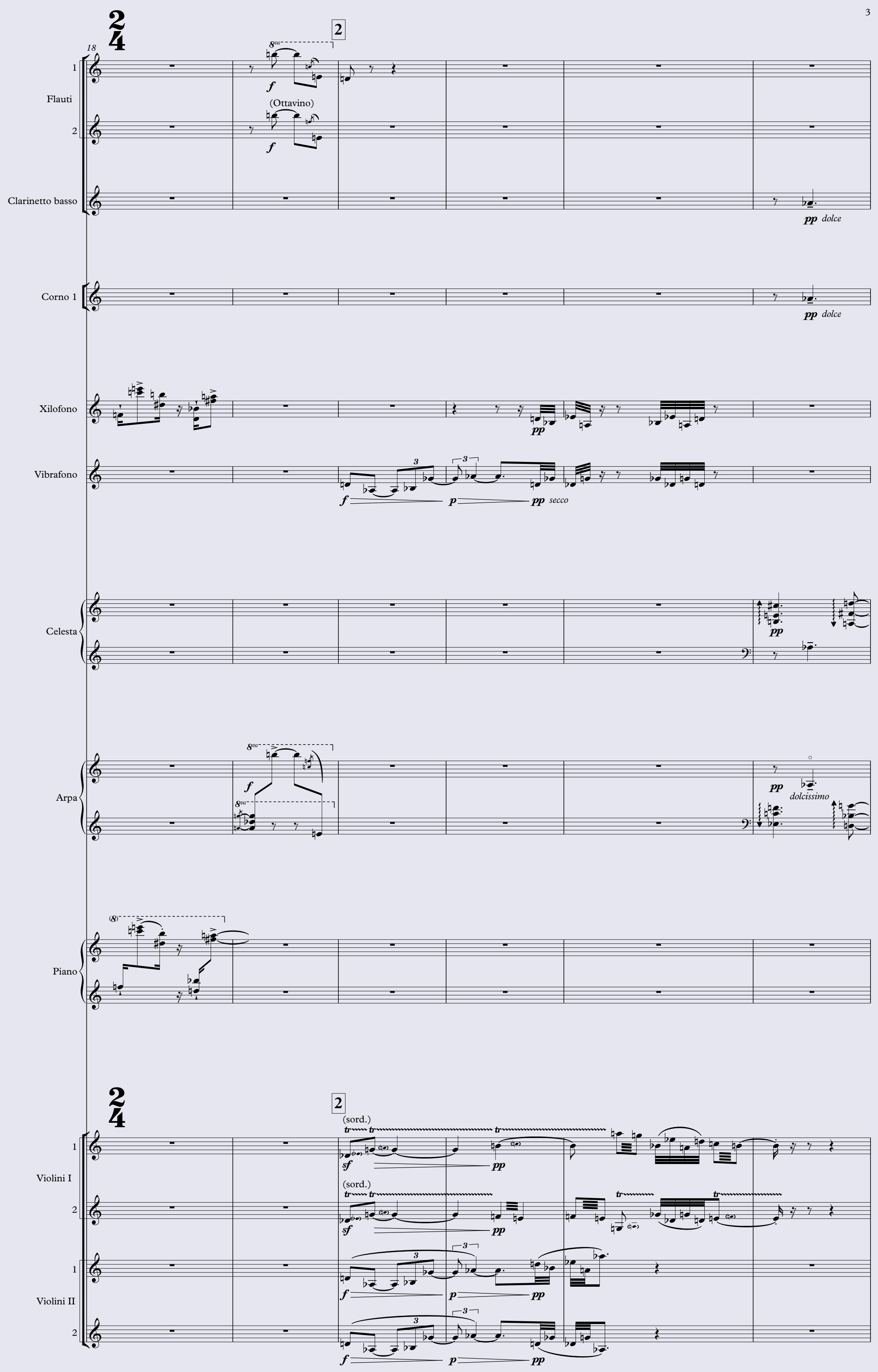


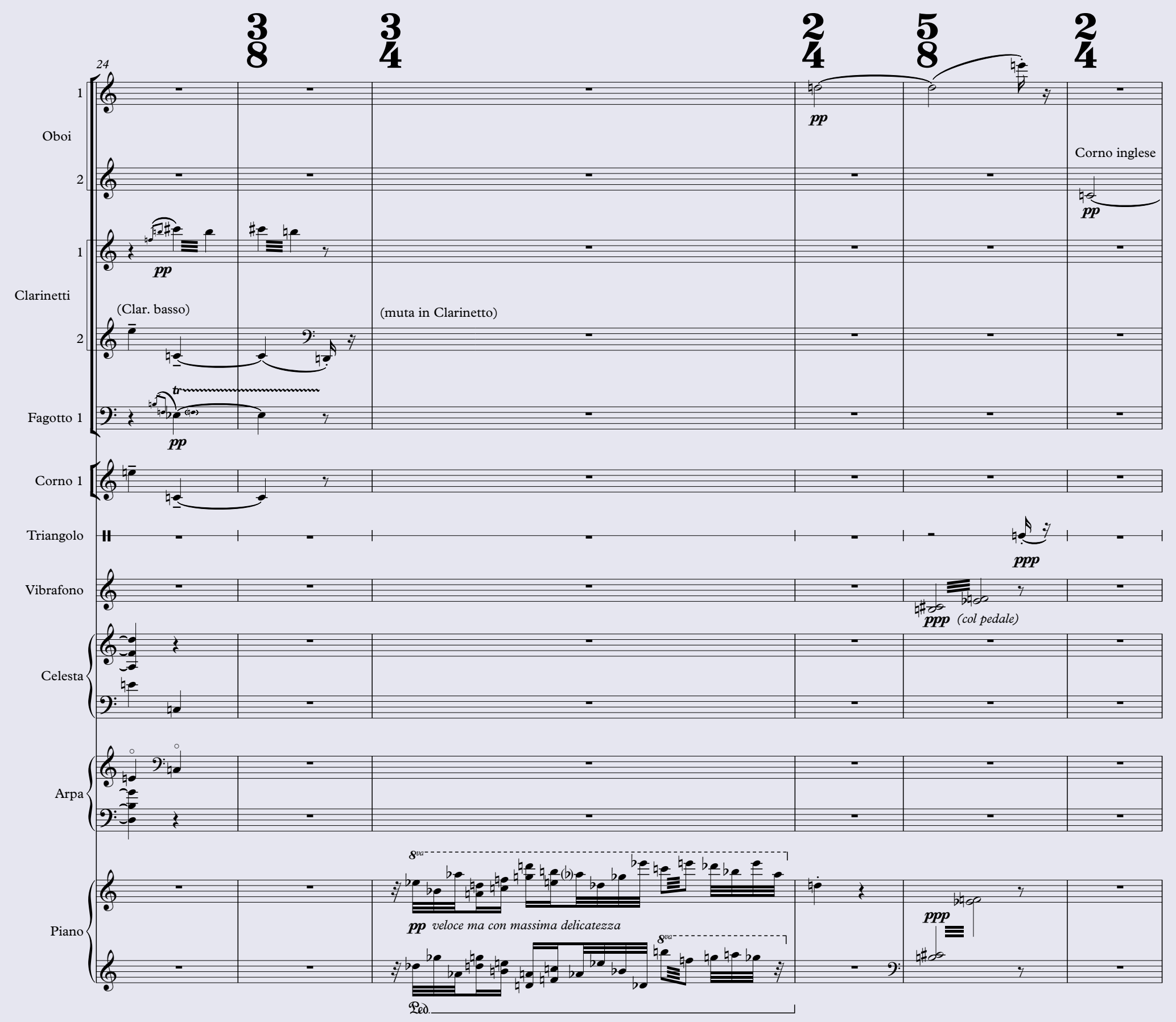

$=$
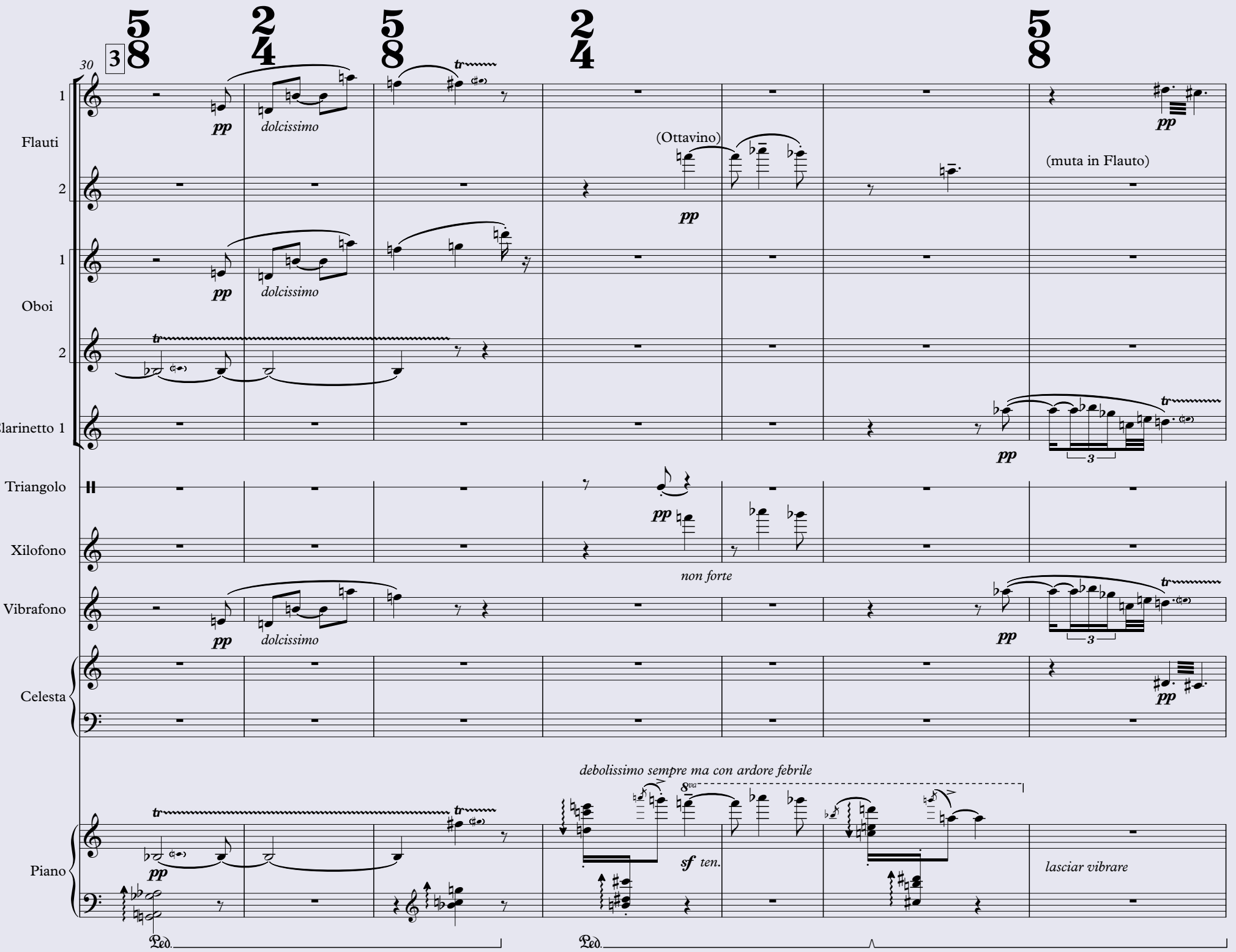
Revista del Departamento de Música - Grupo de investigación en Estudios musicales RICERCARE
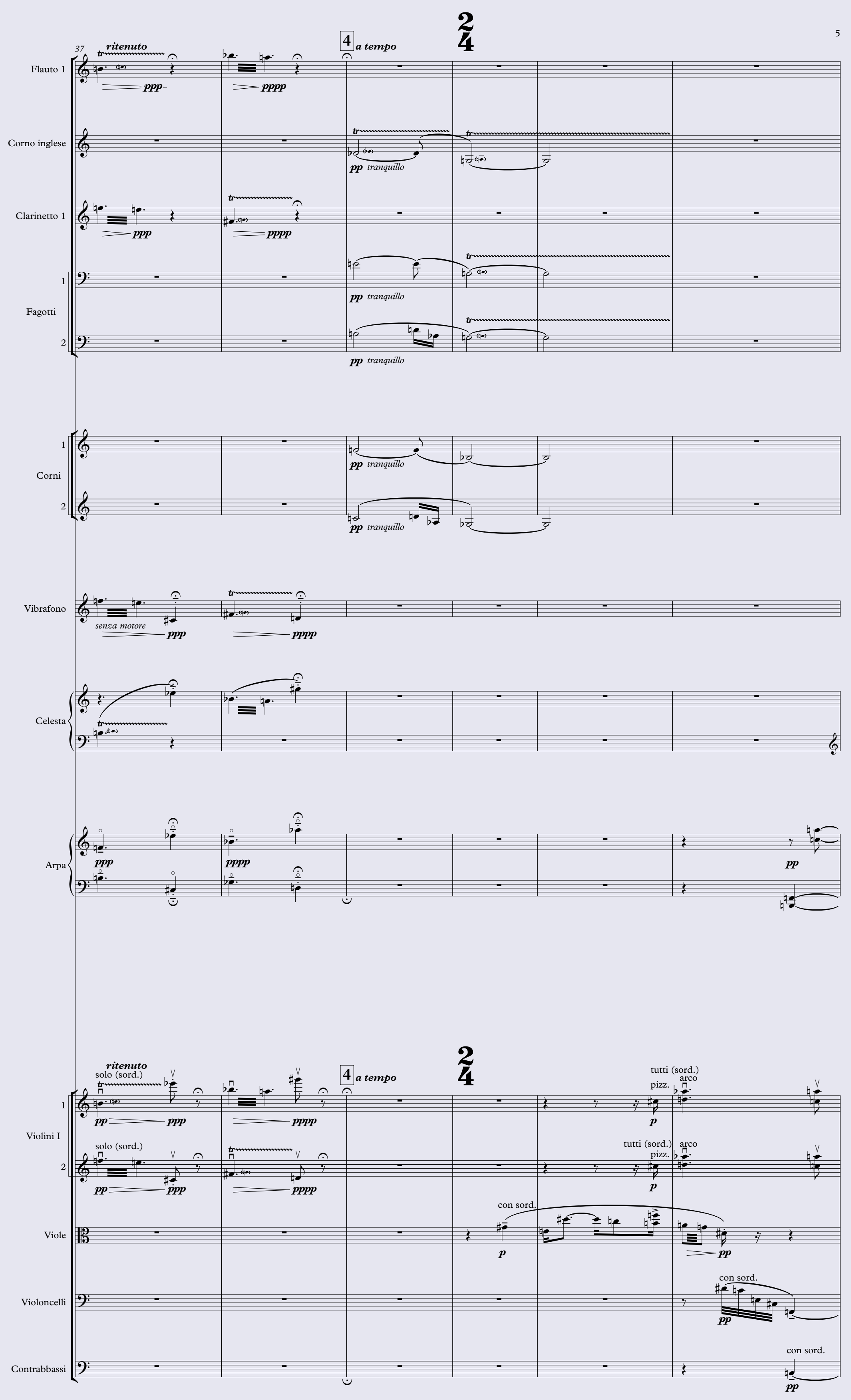

Núm. 14 (2021) 10 


\section{8}
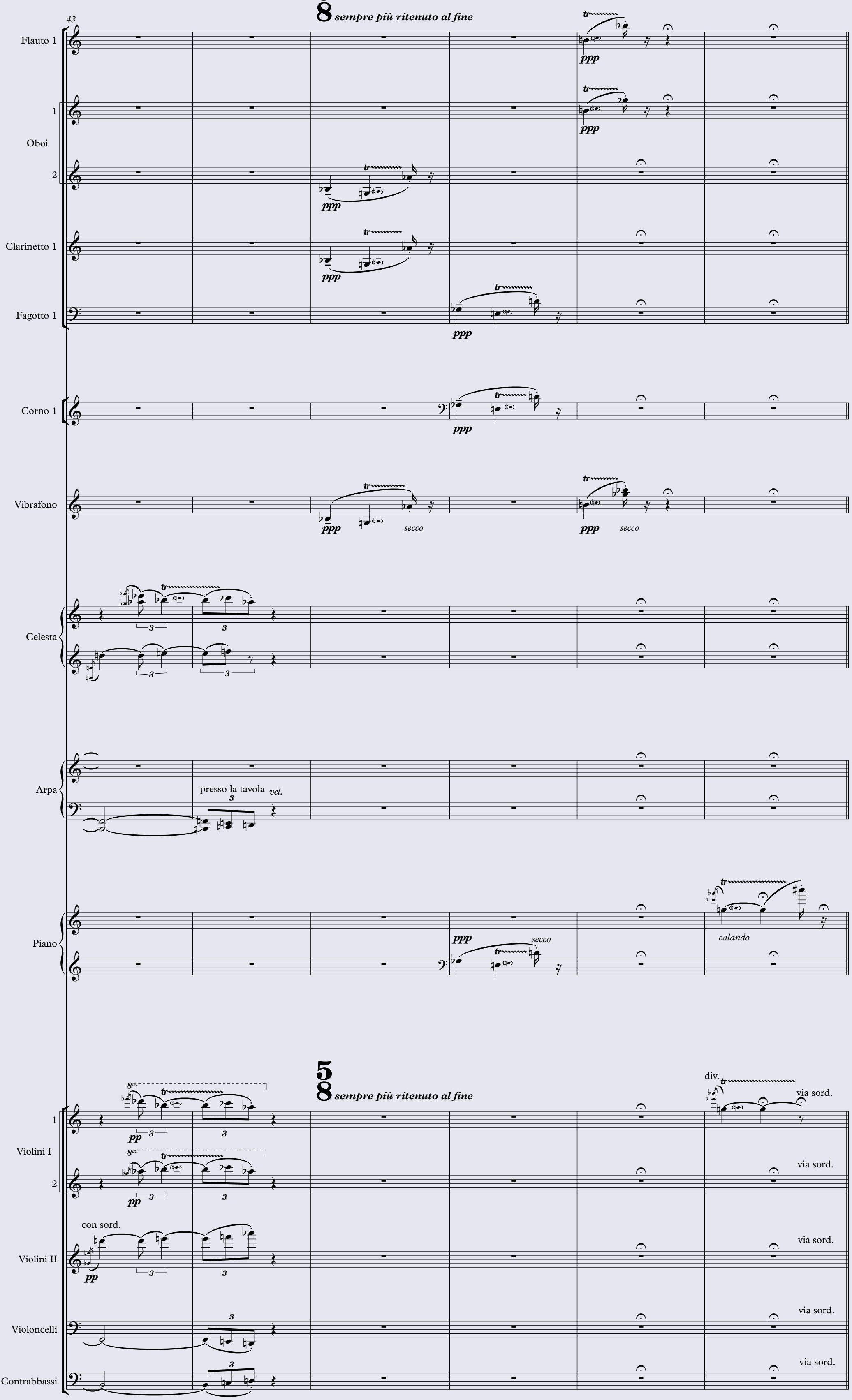


\section{II}

Great Chaos under Heaven

天下大亂
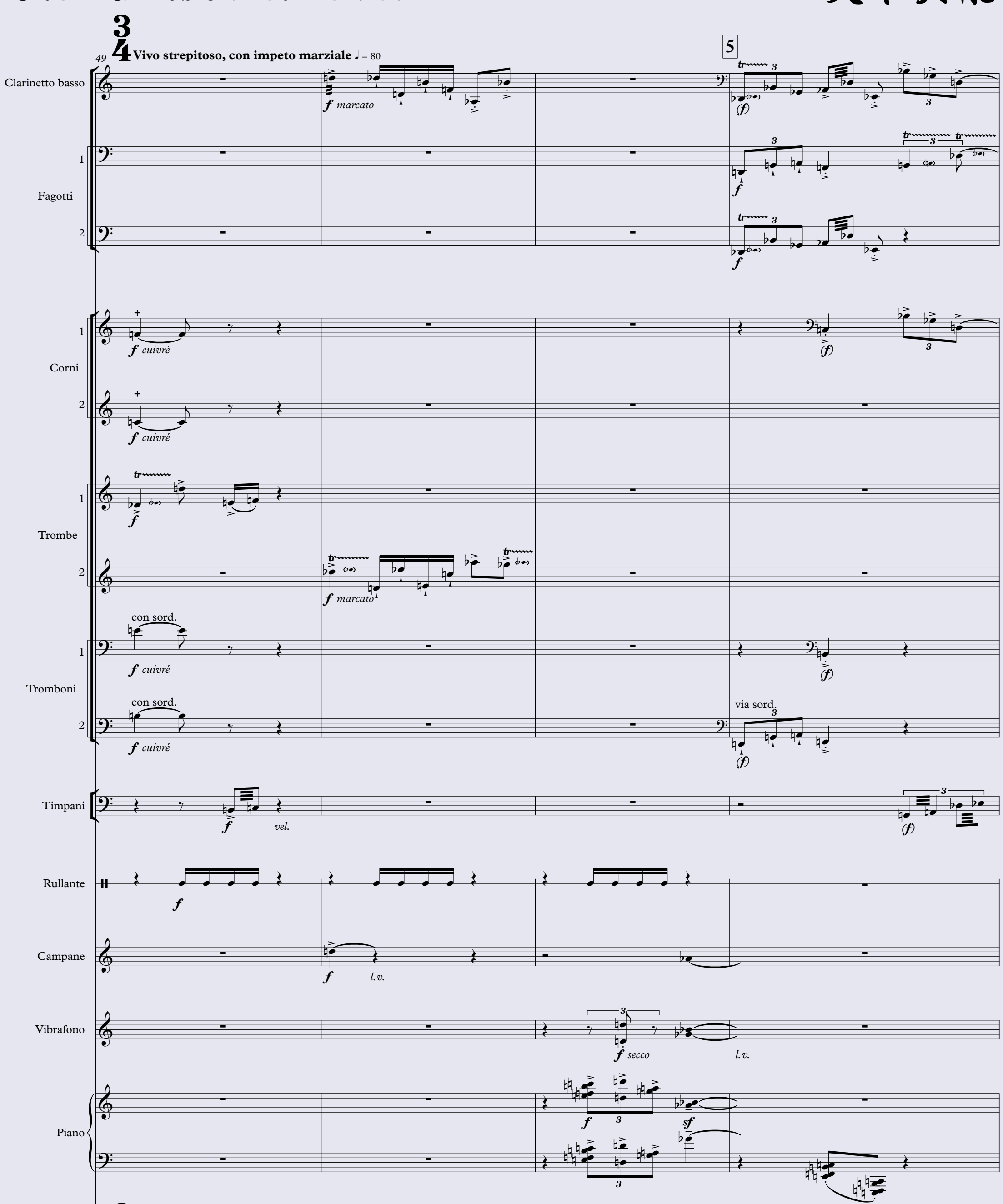

3

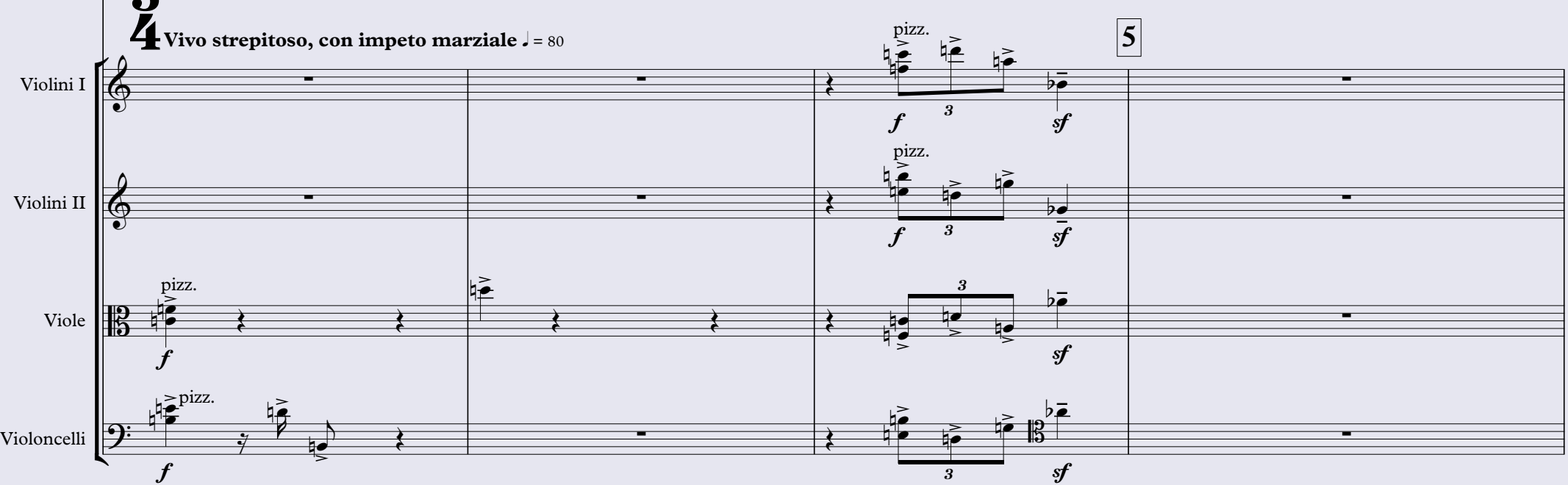



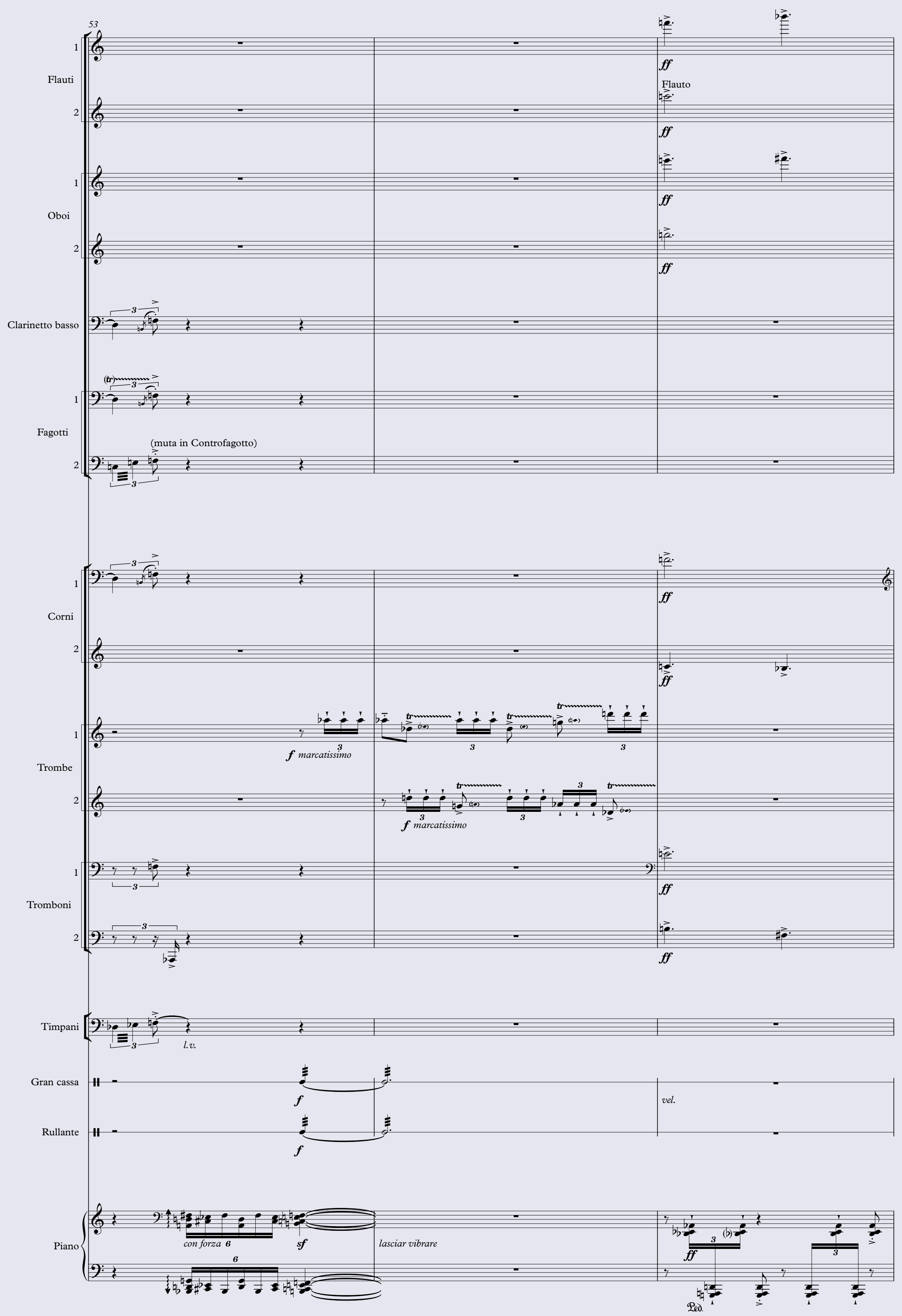

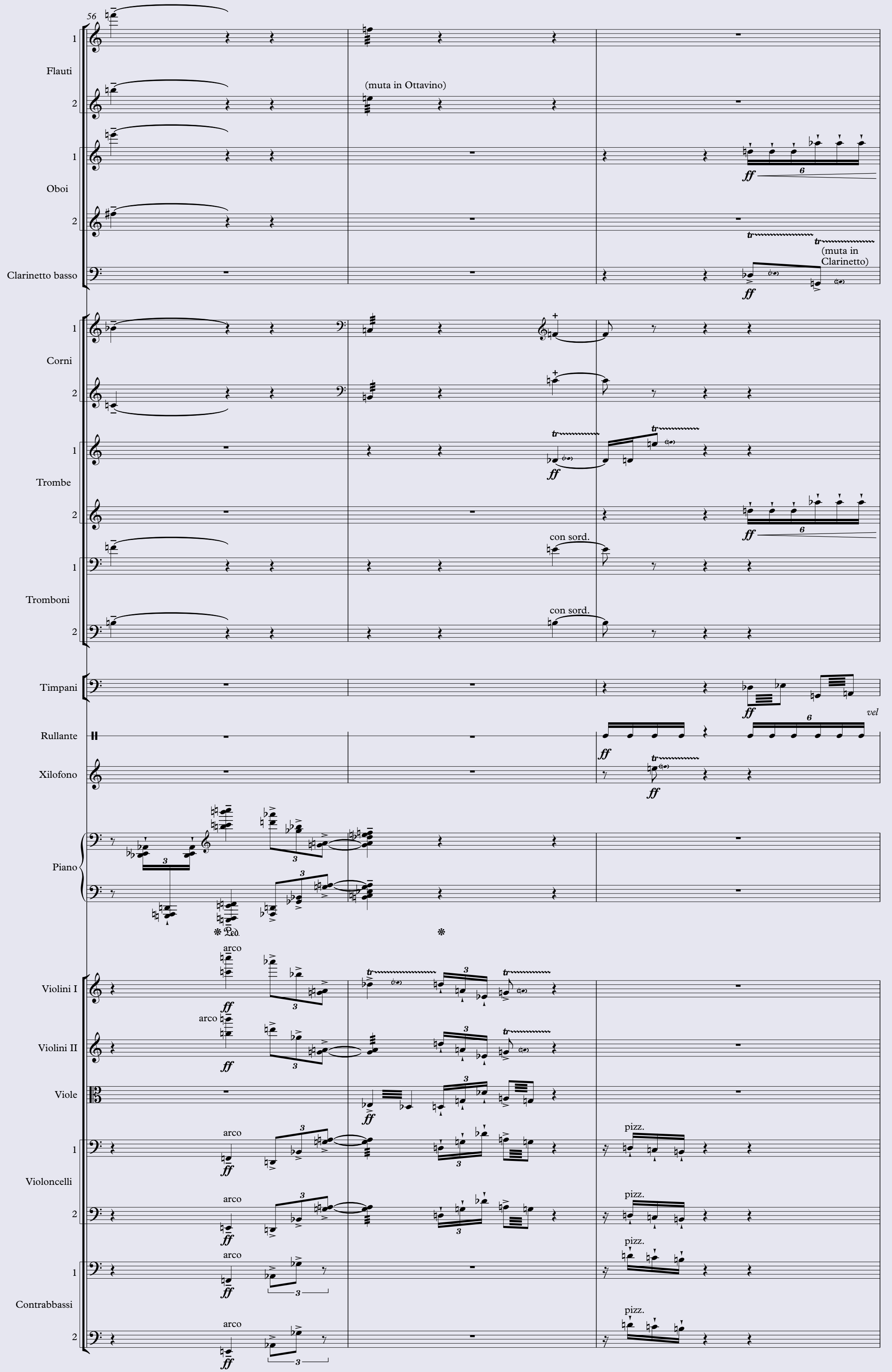


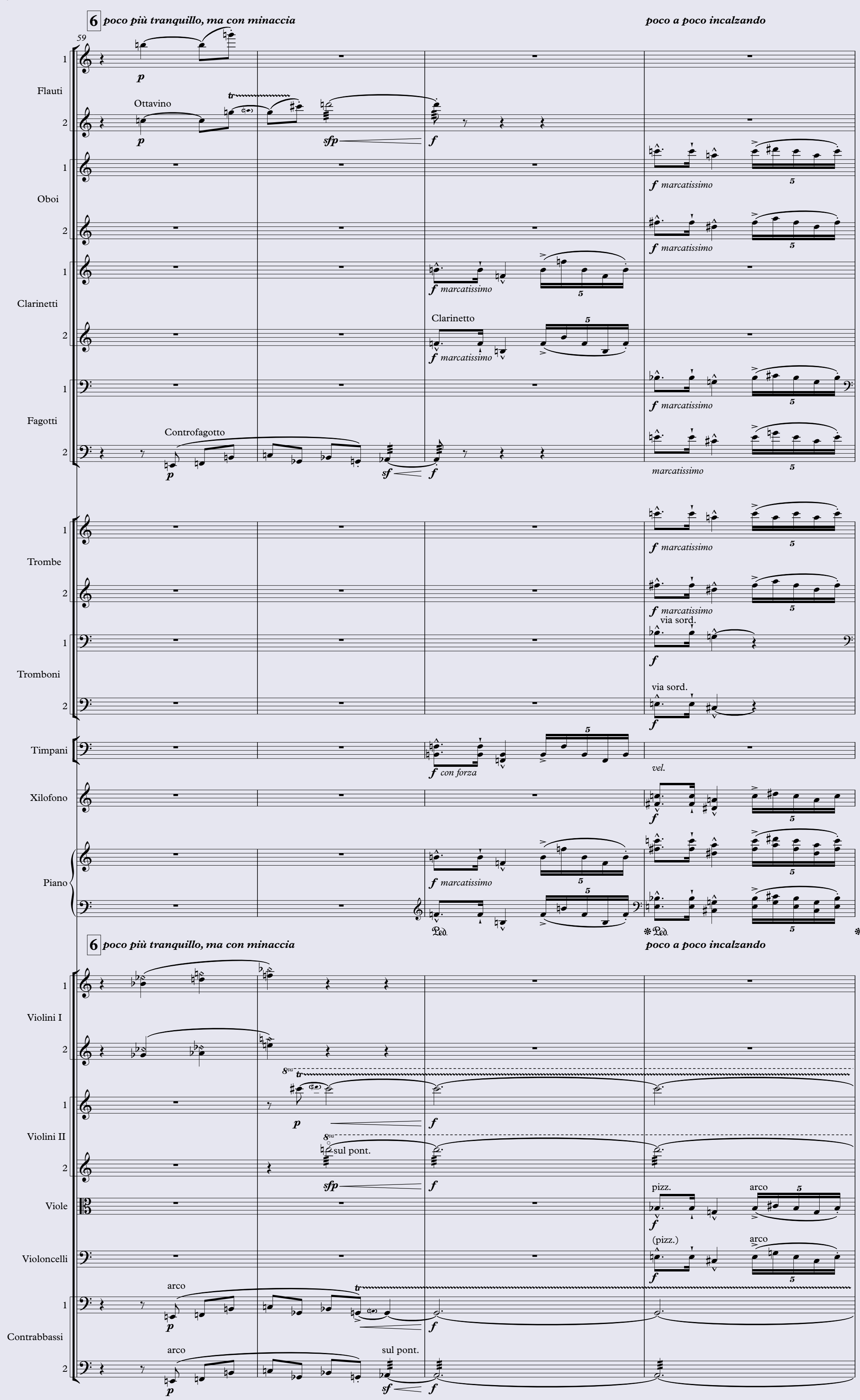



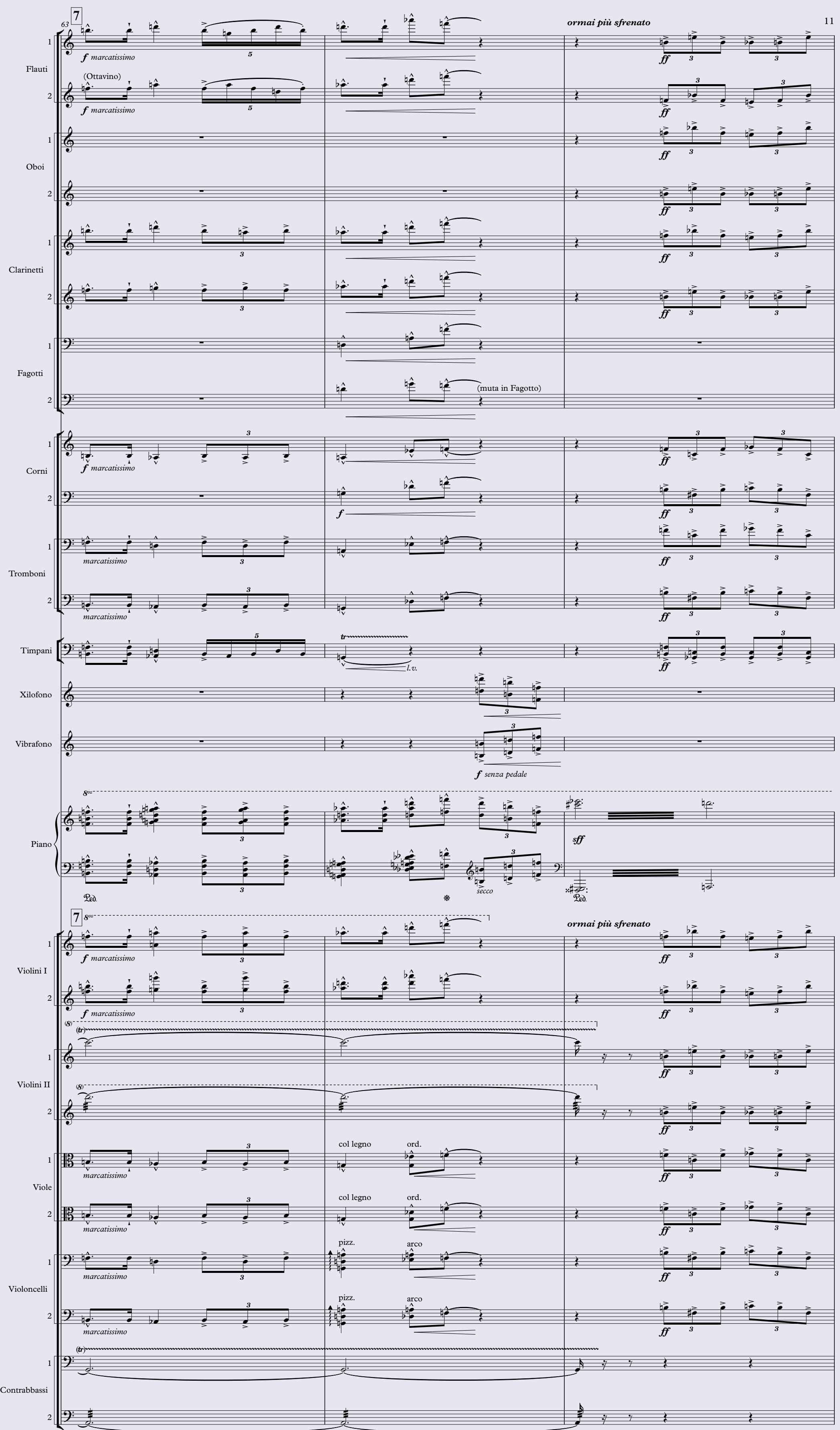


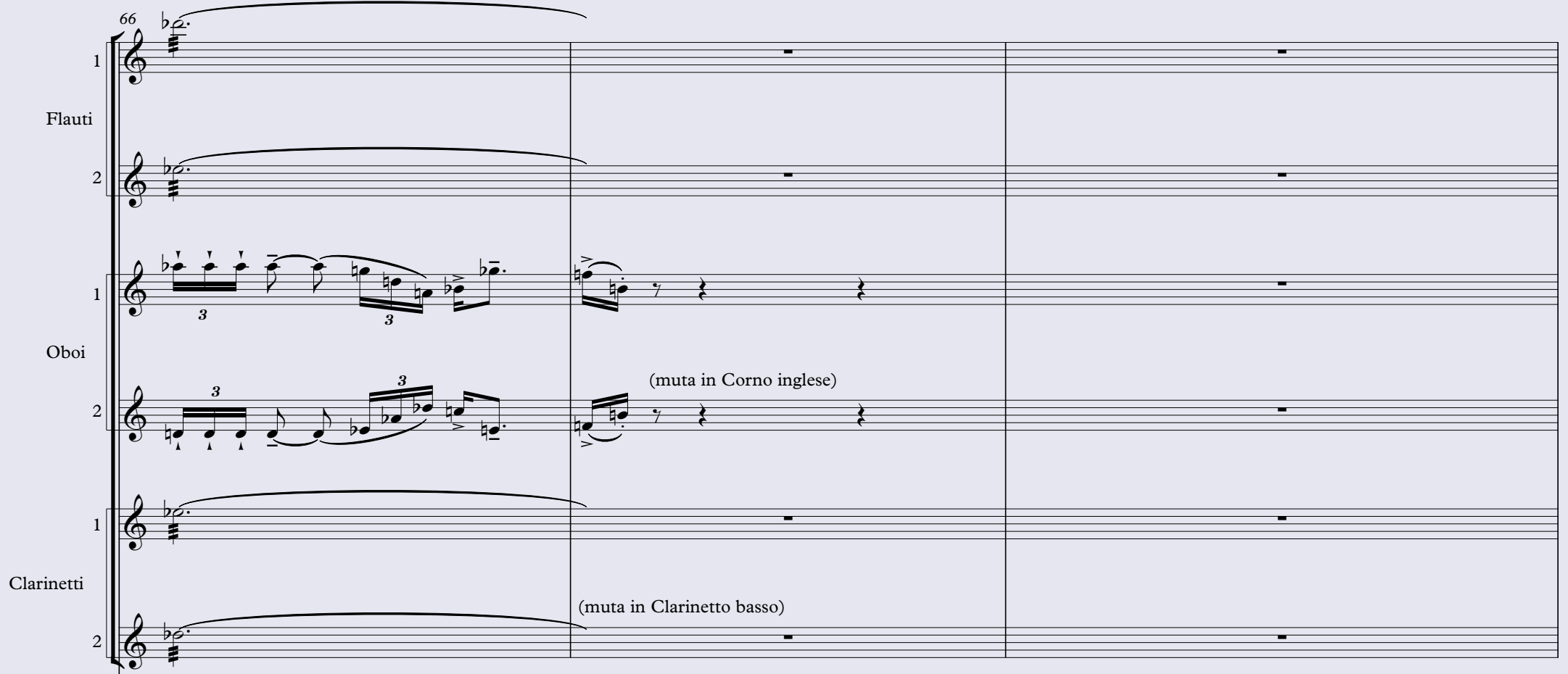

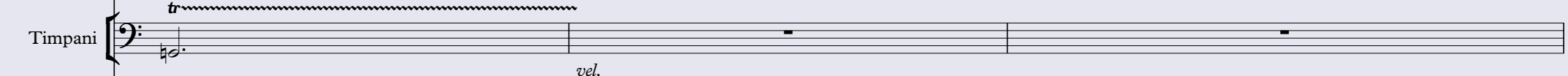

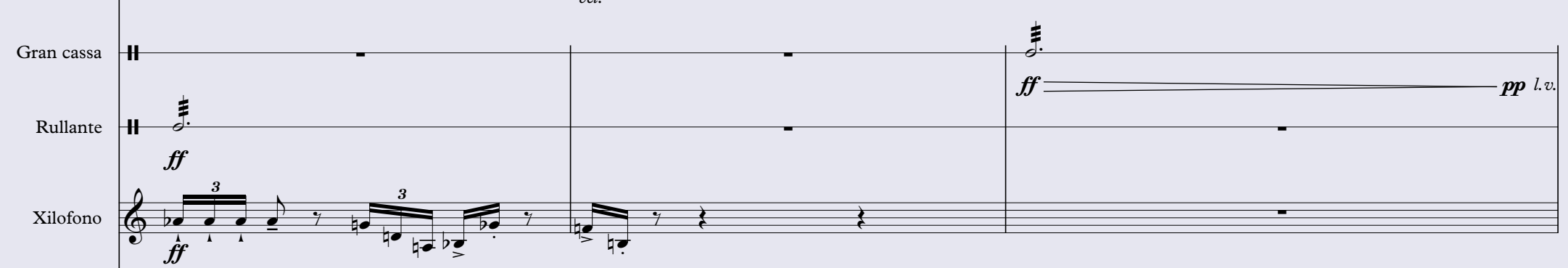

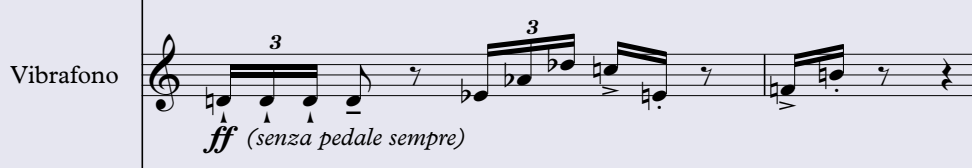
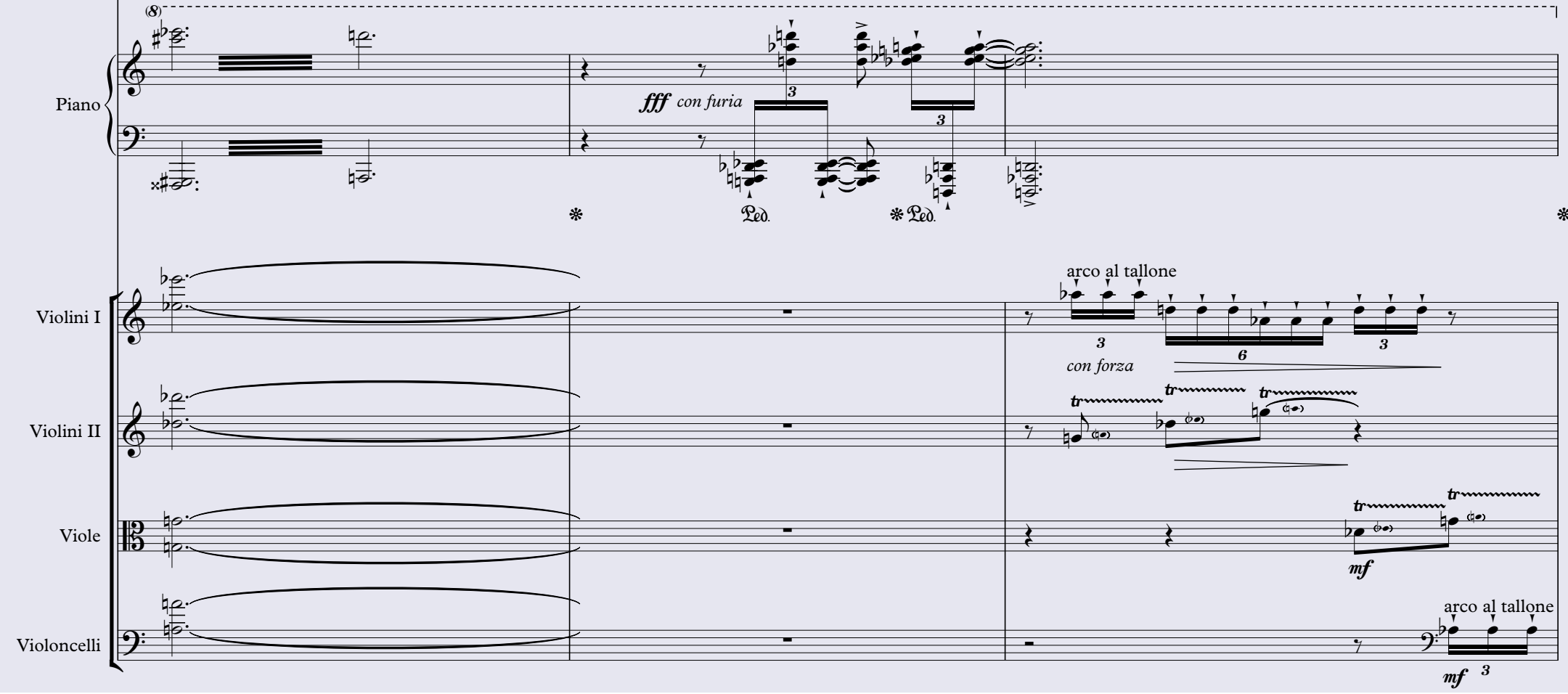

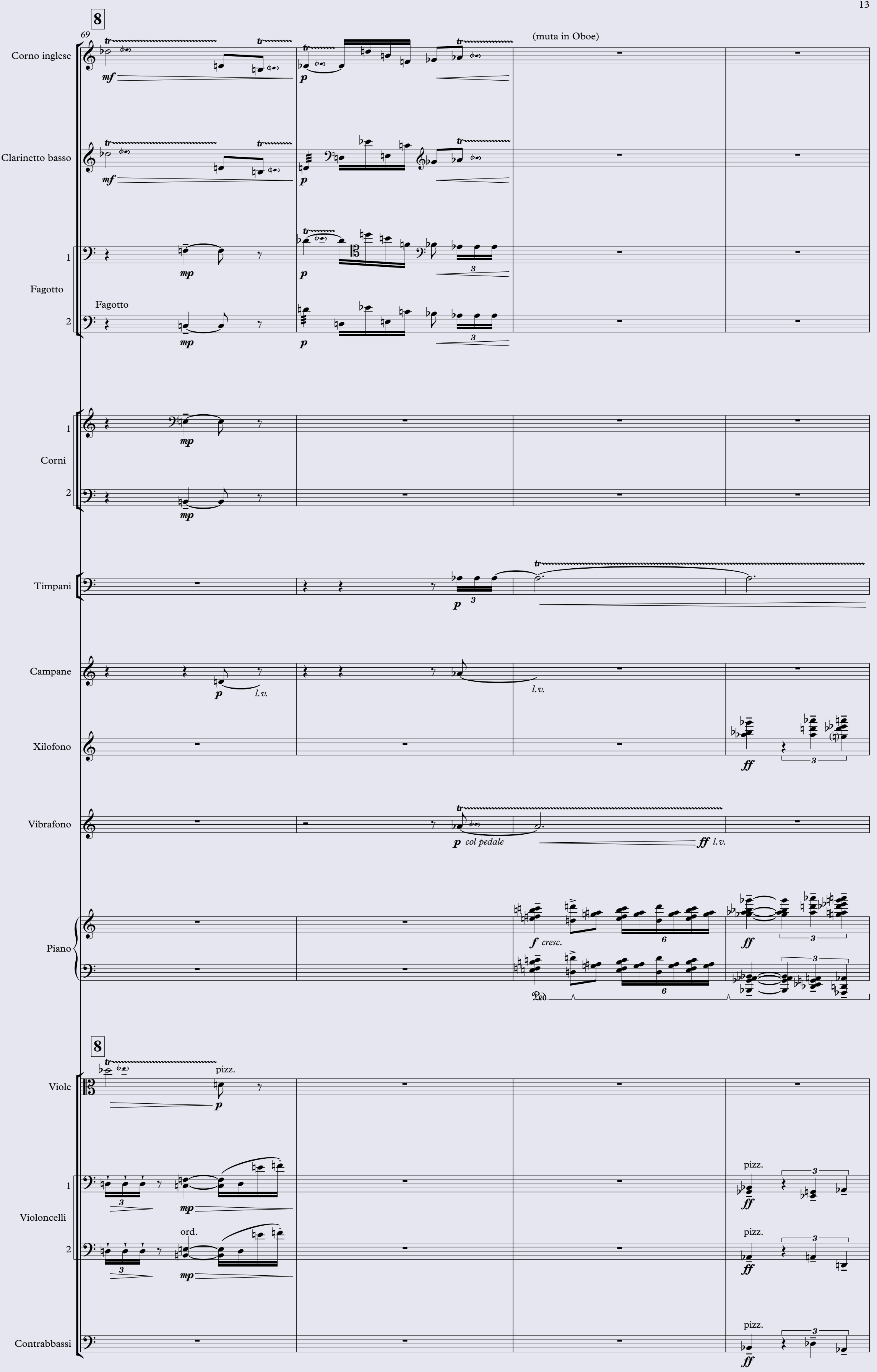


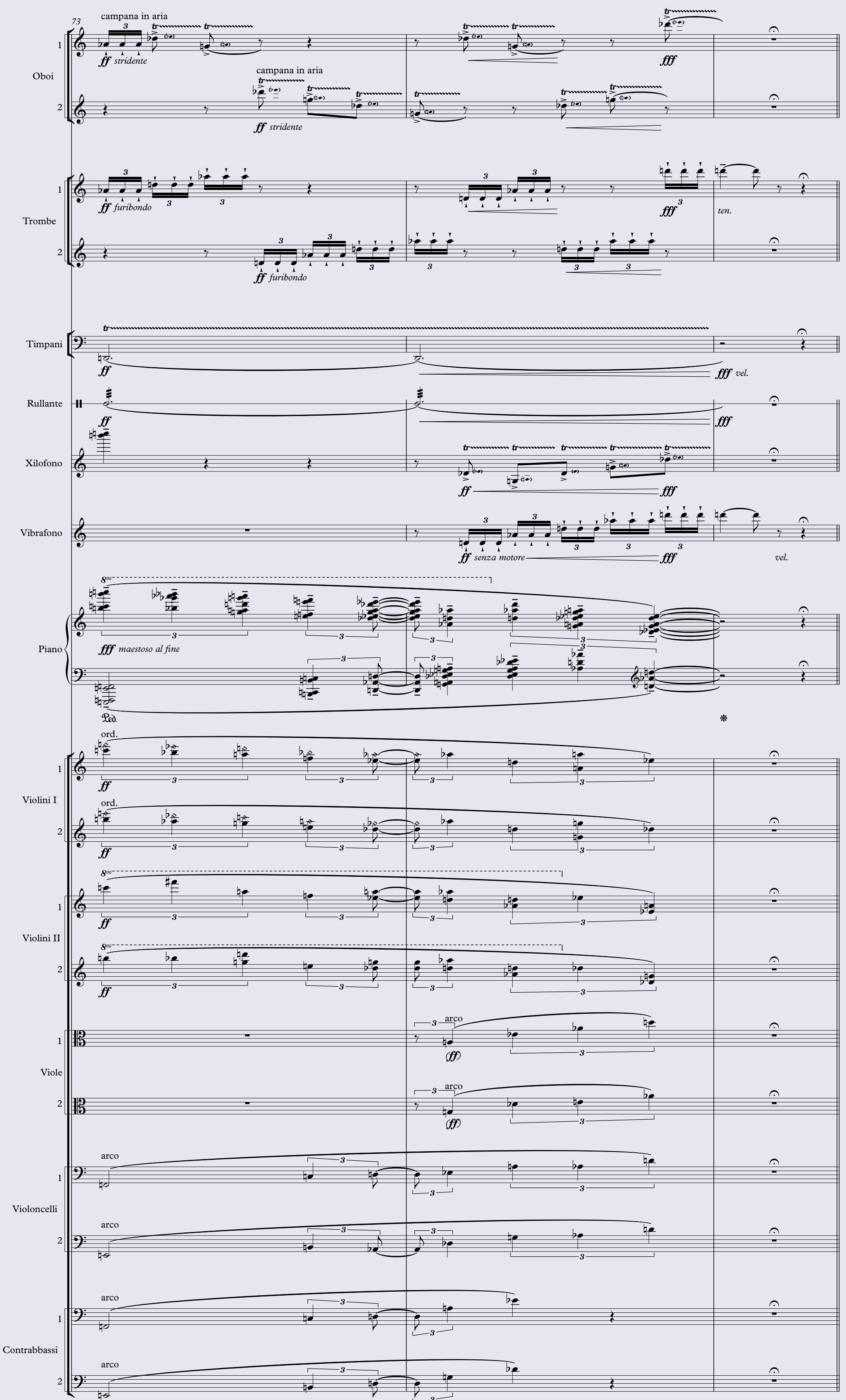




\section{III}

\section{ANGIENT NANJING}
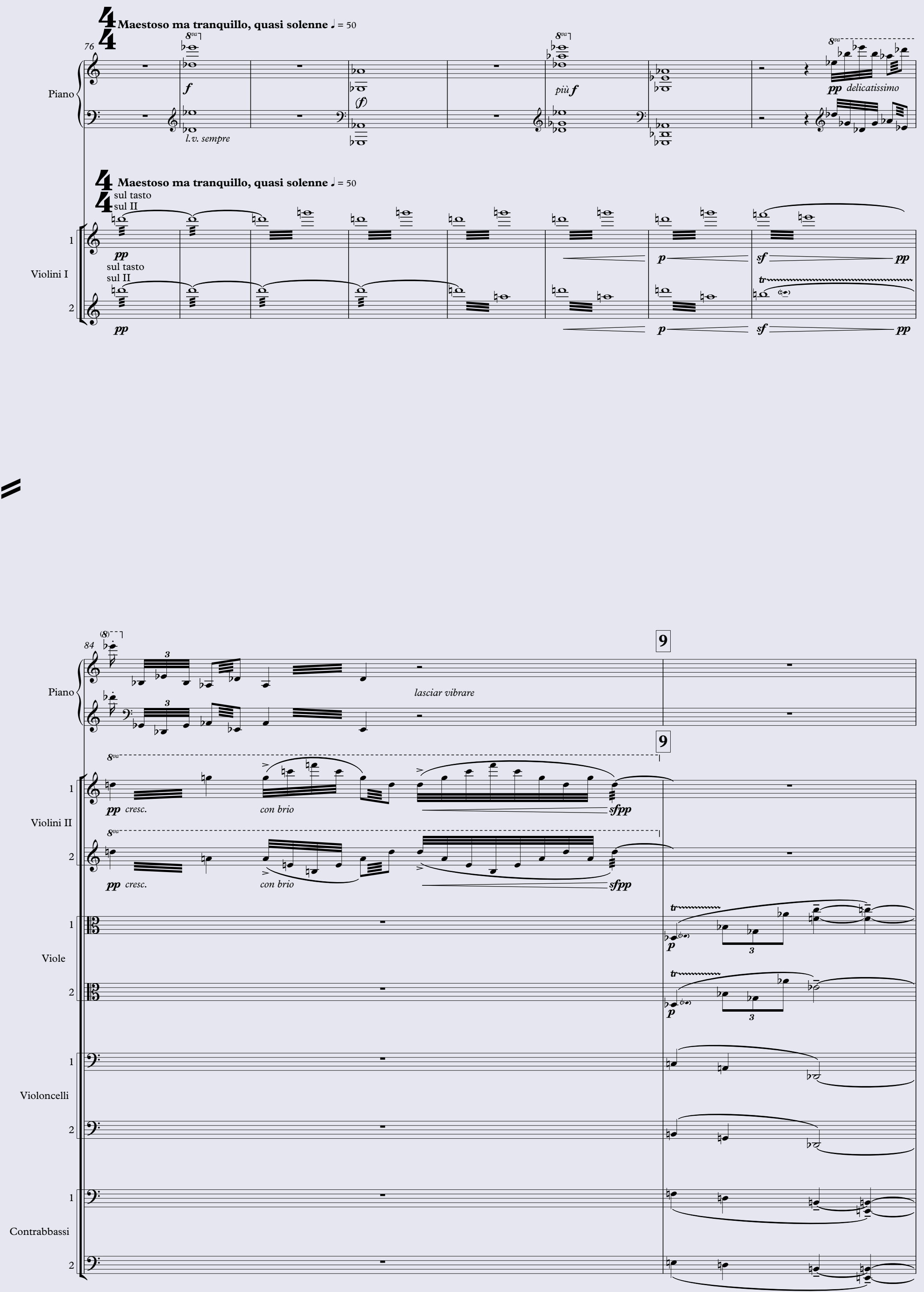


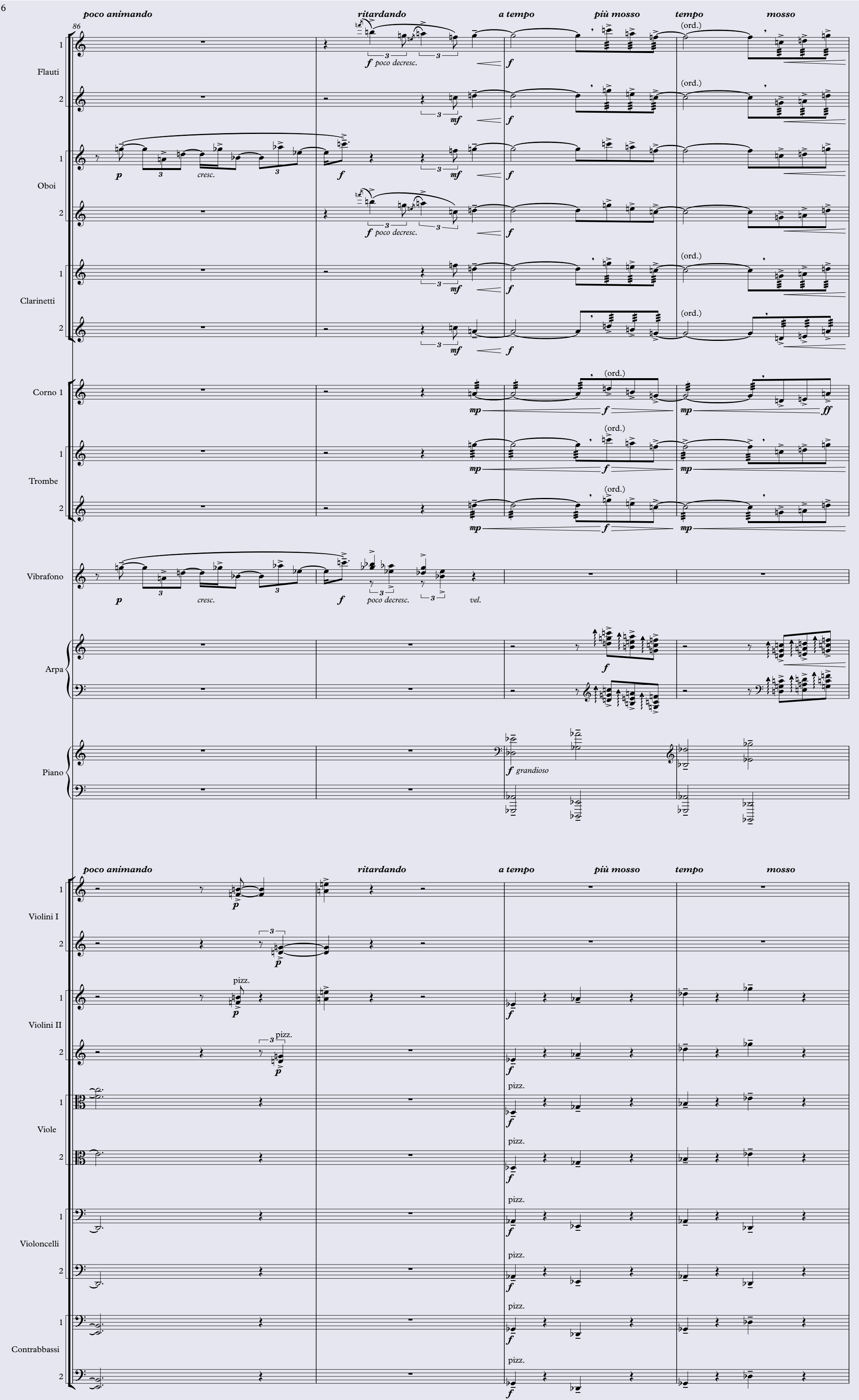



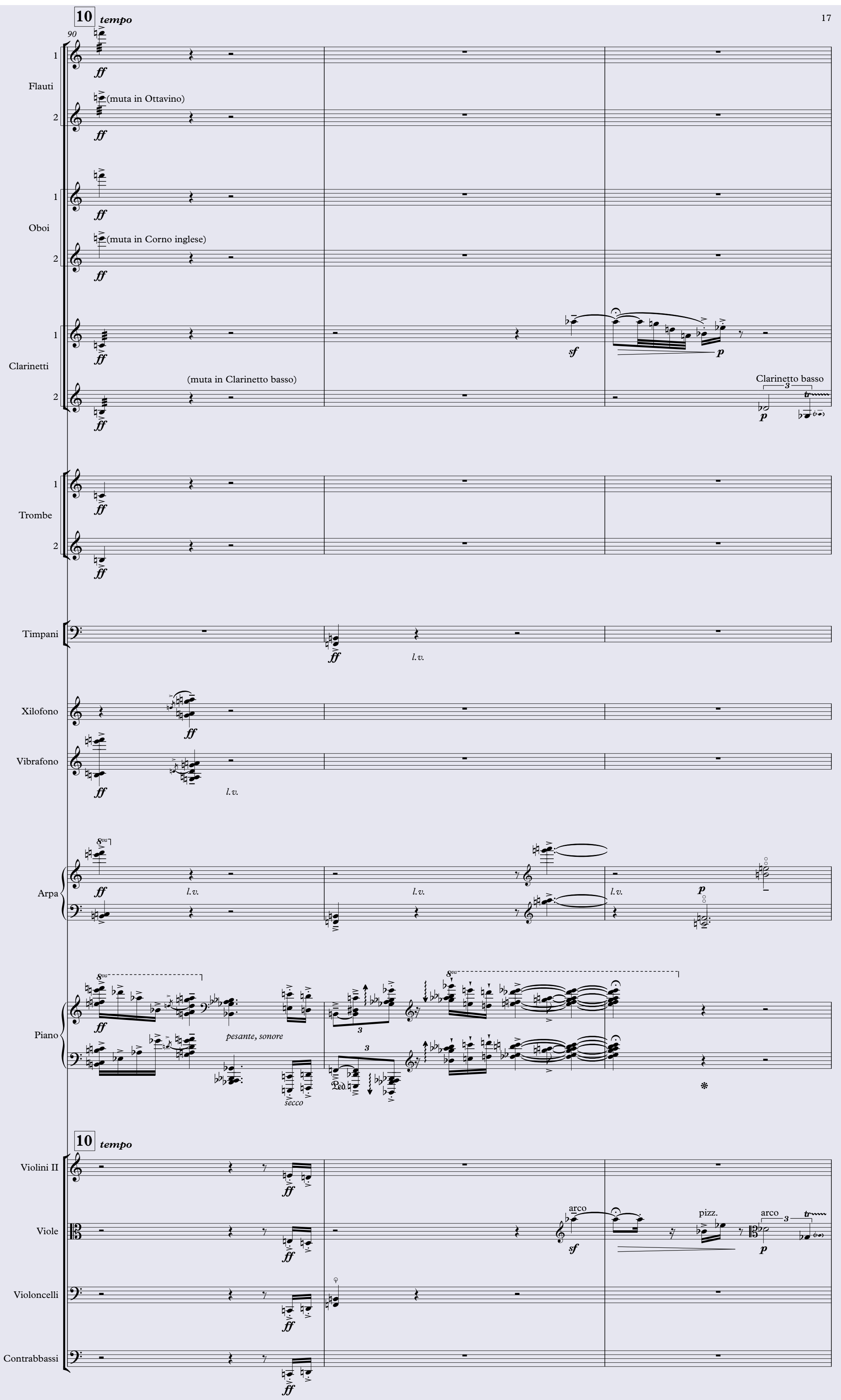


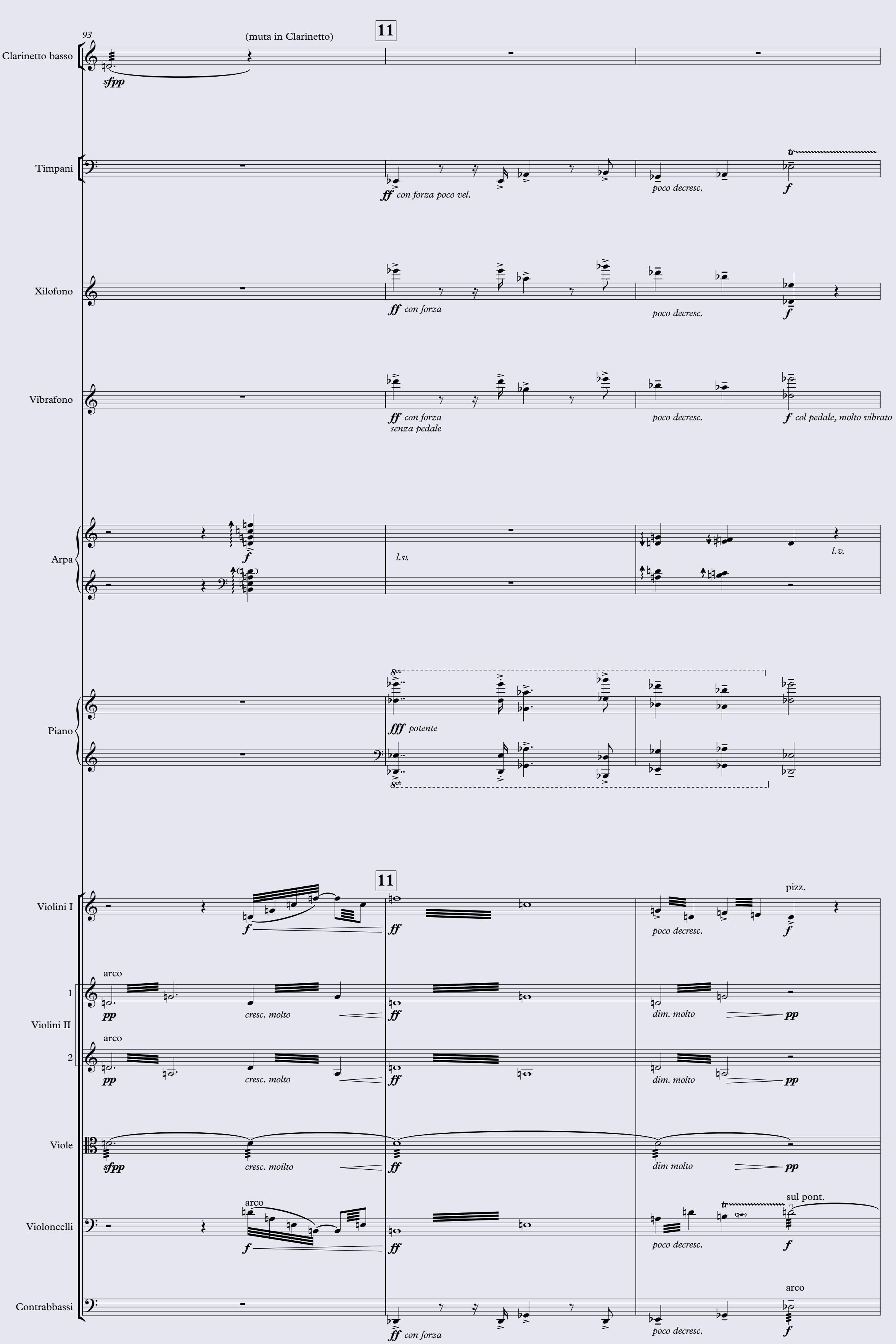



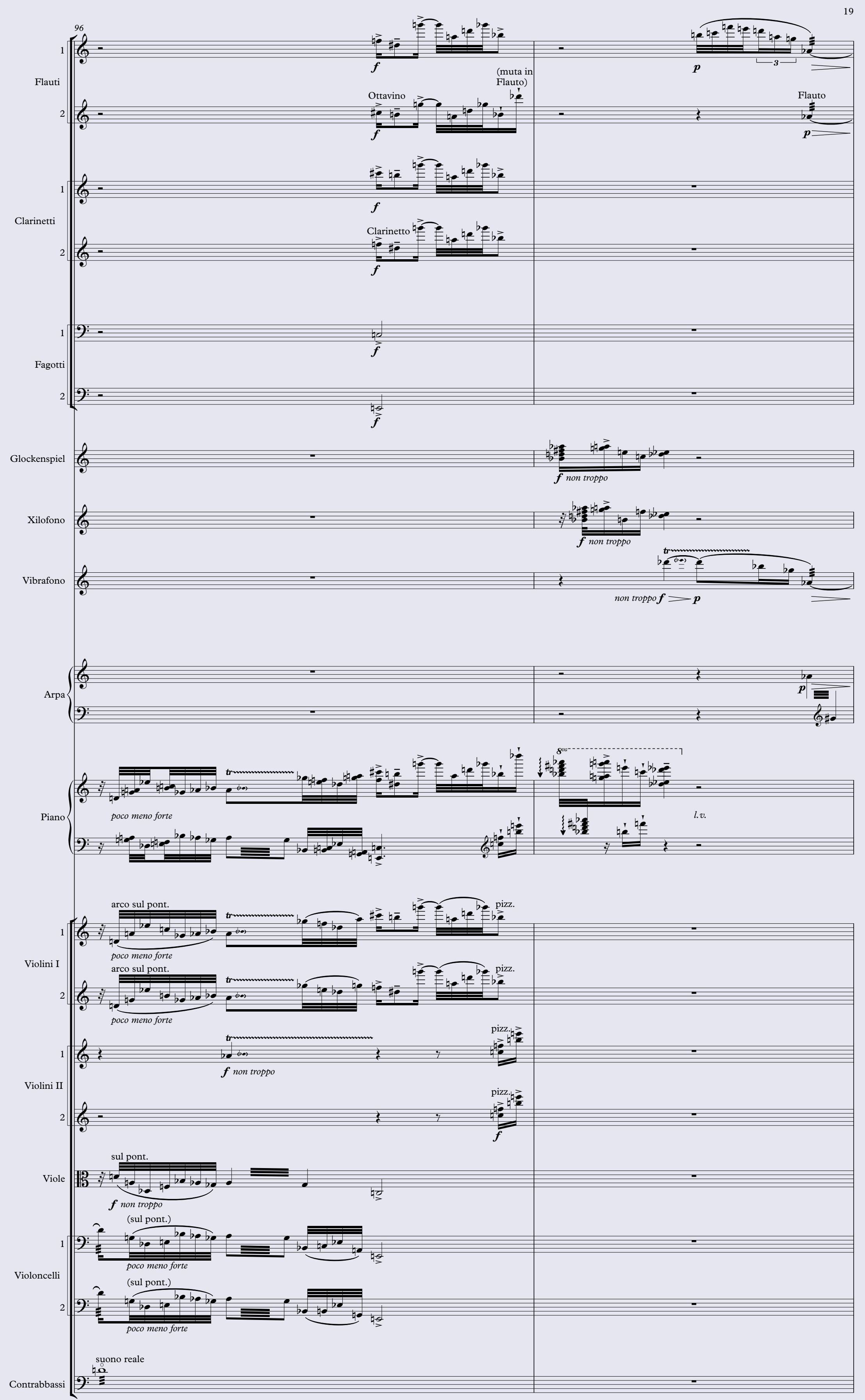

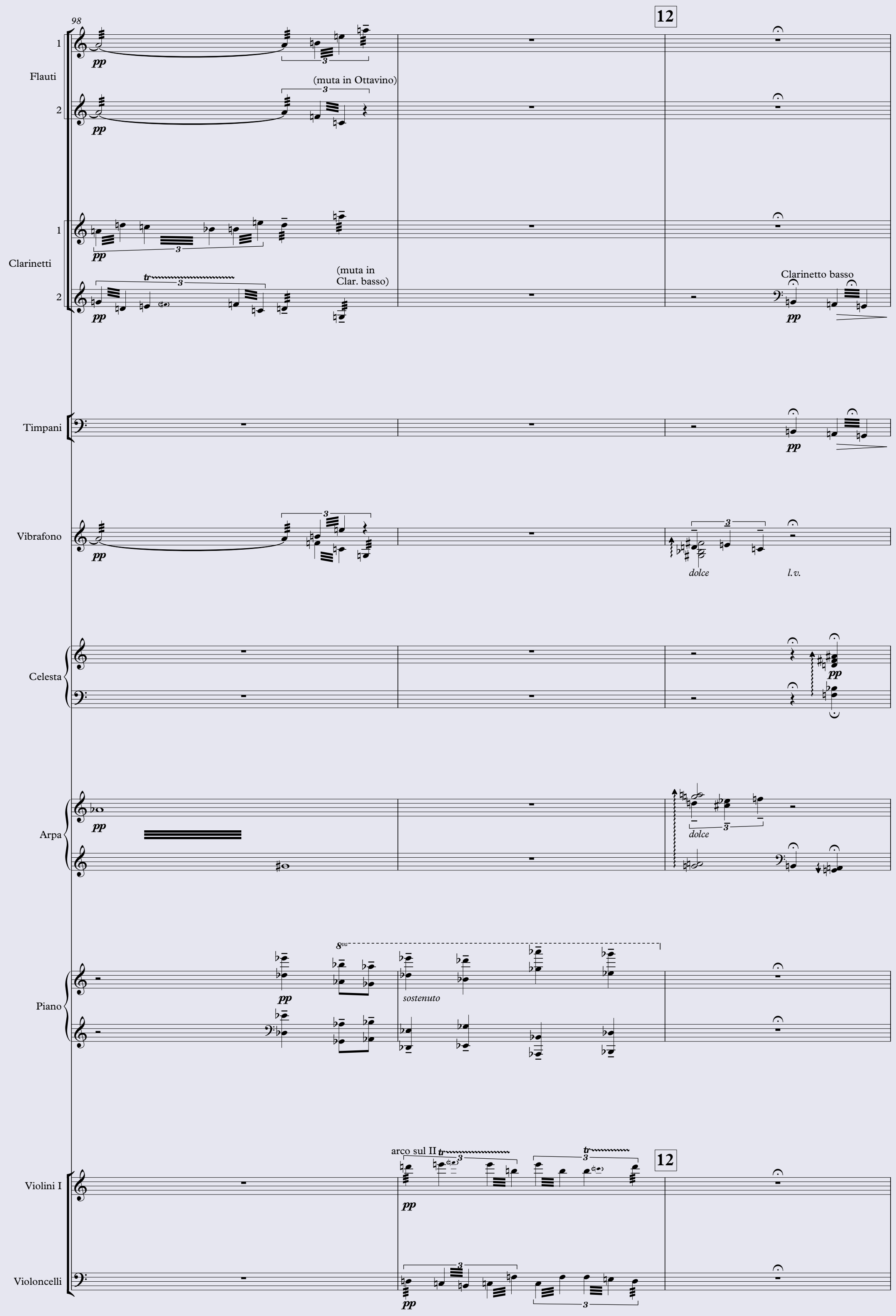


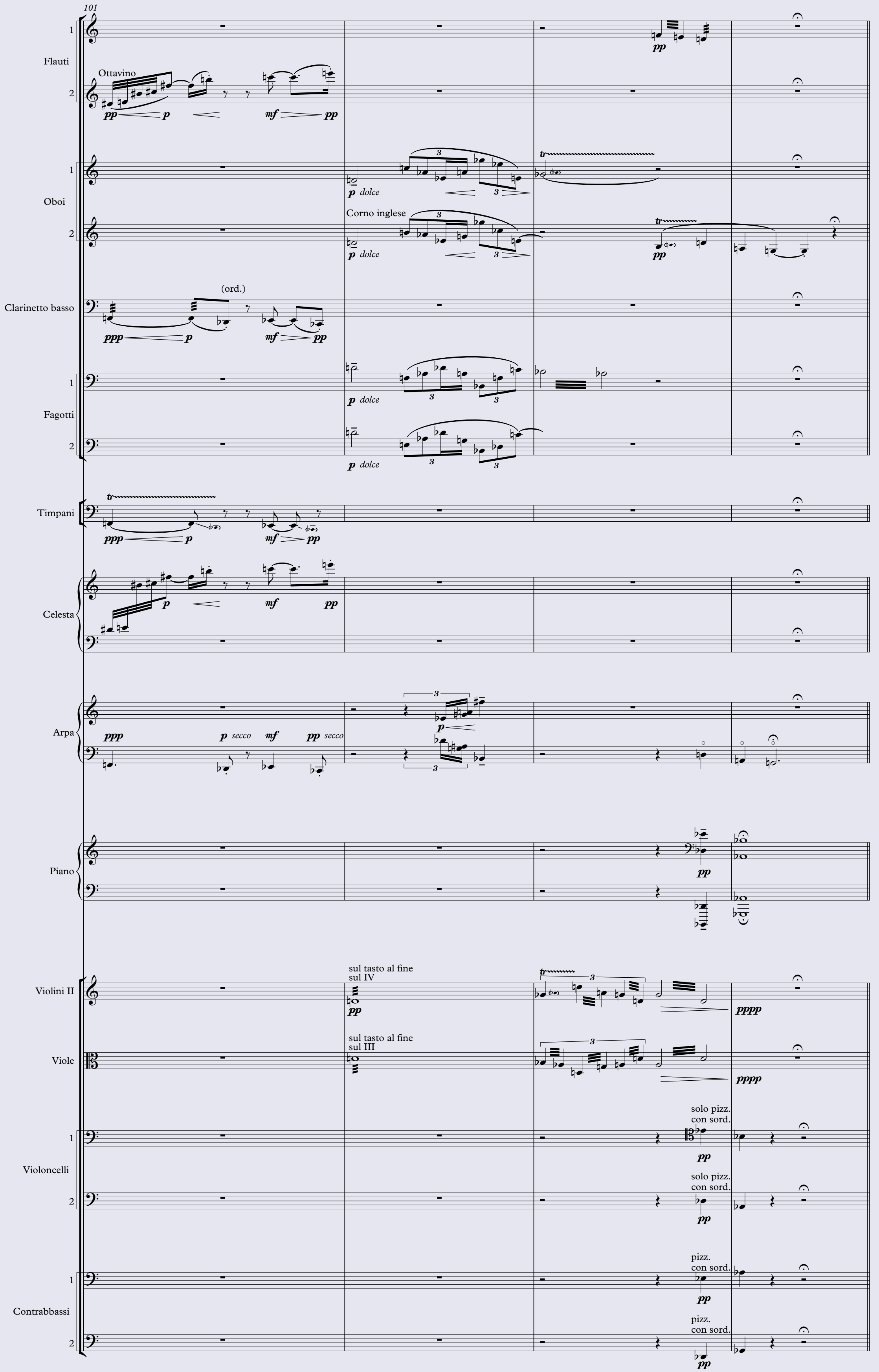




\section{IV}

Staring Wei Je to Death

看殺衛纵
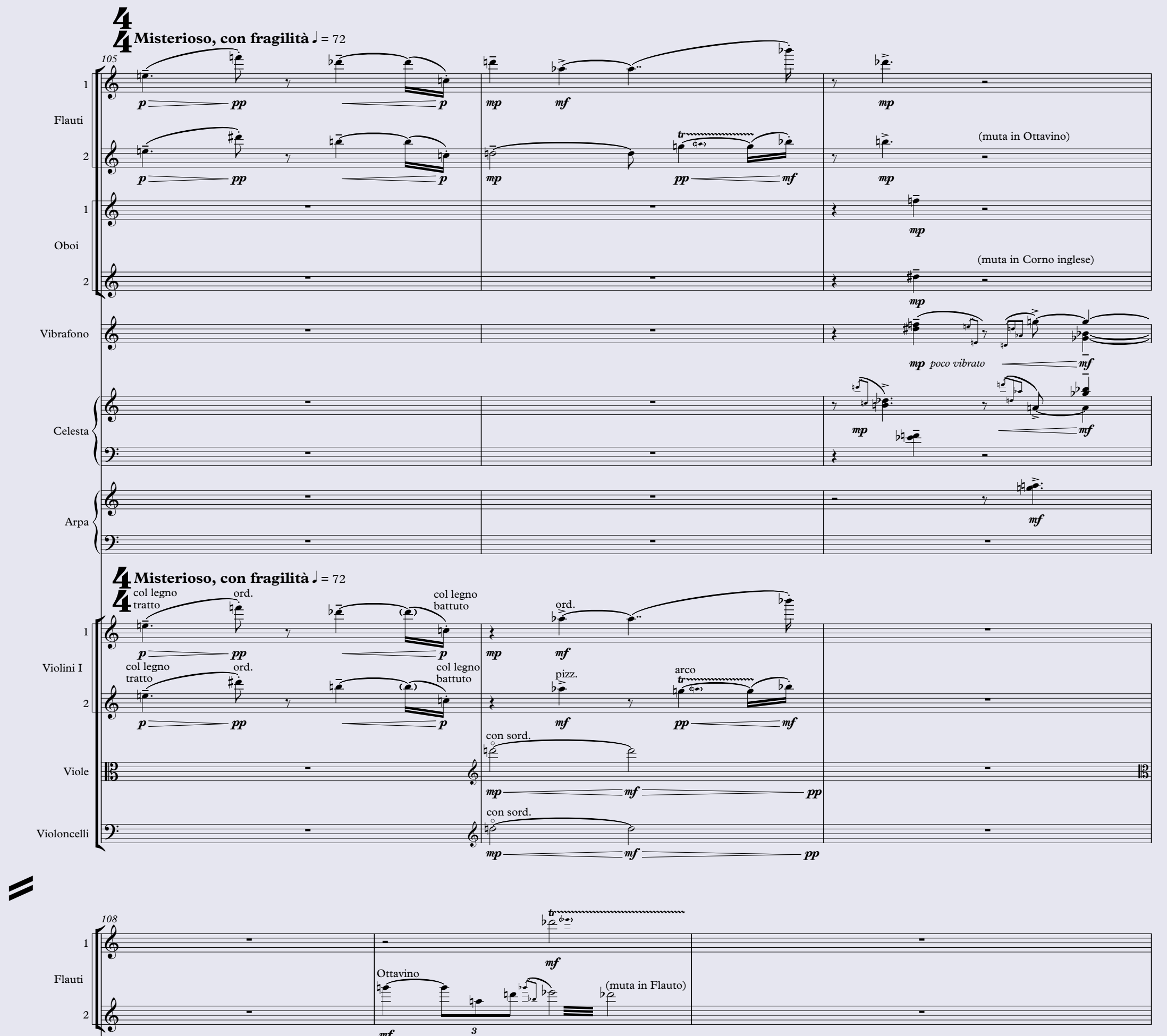

Vibrafono
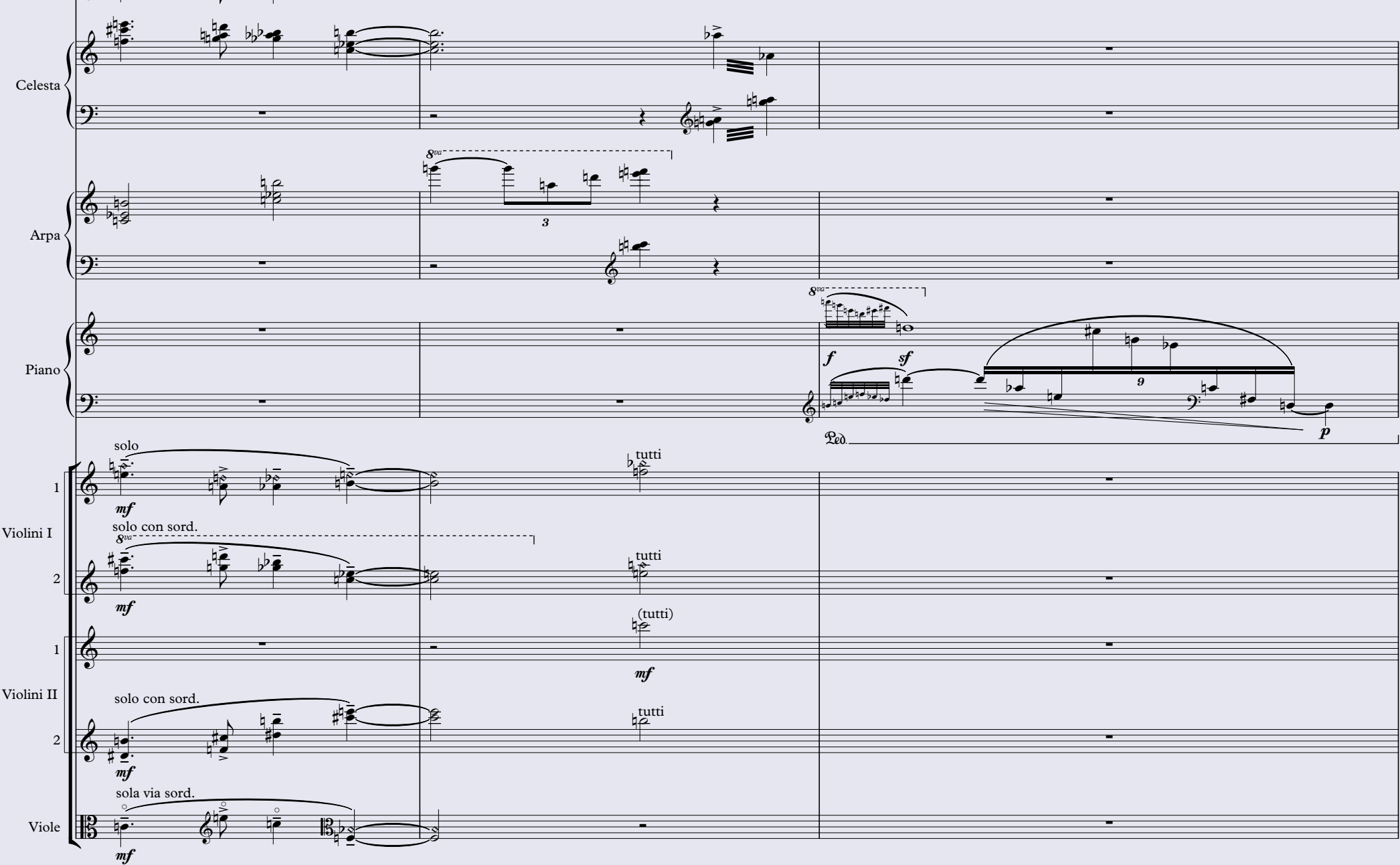
9

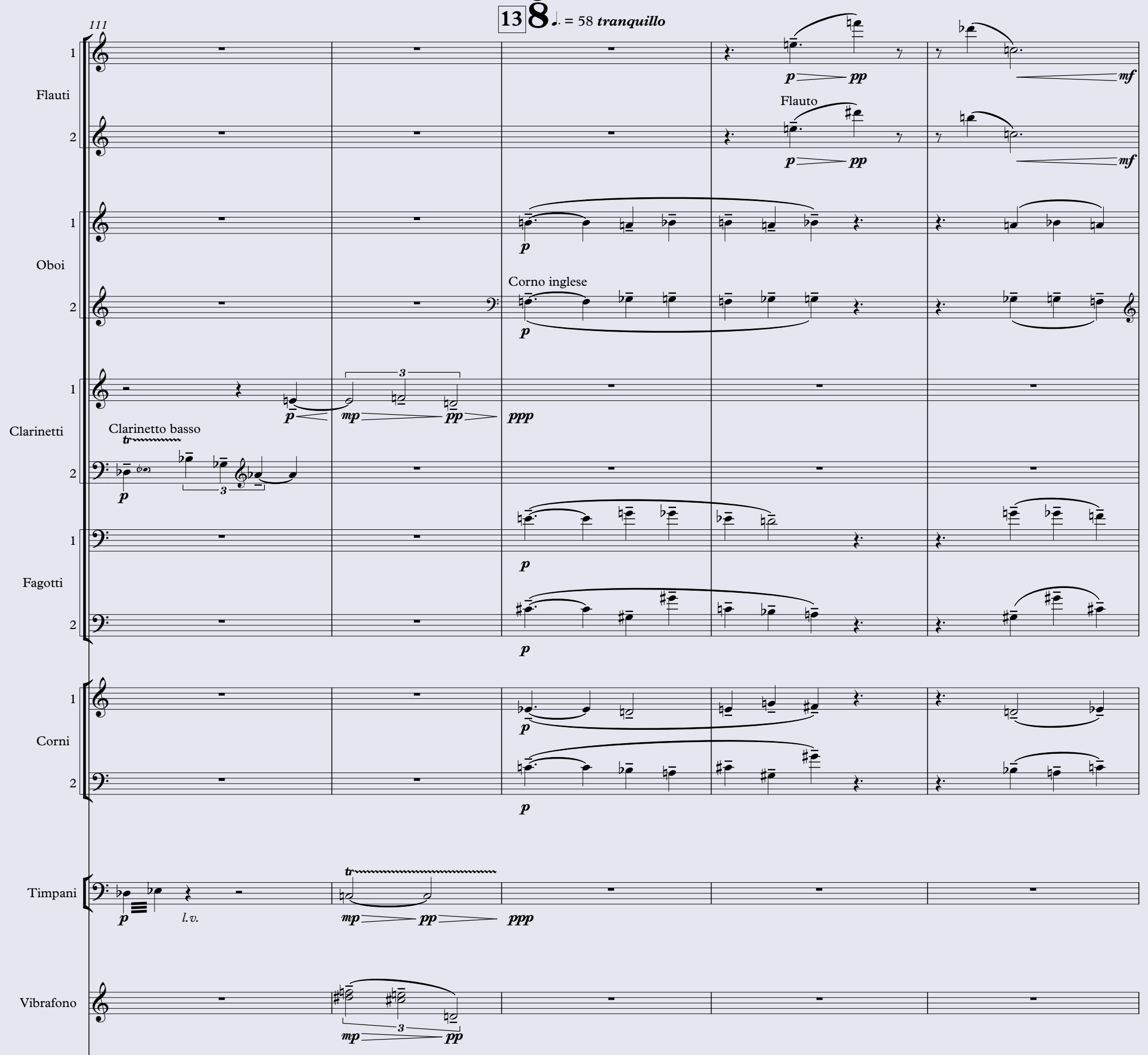

9

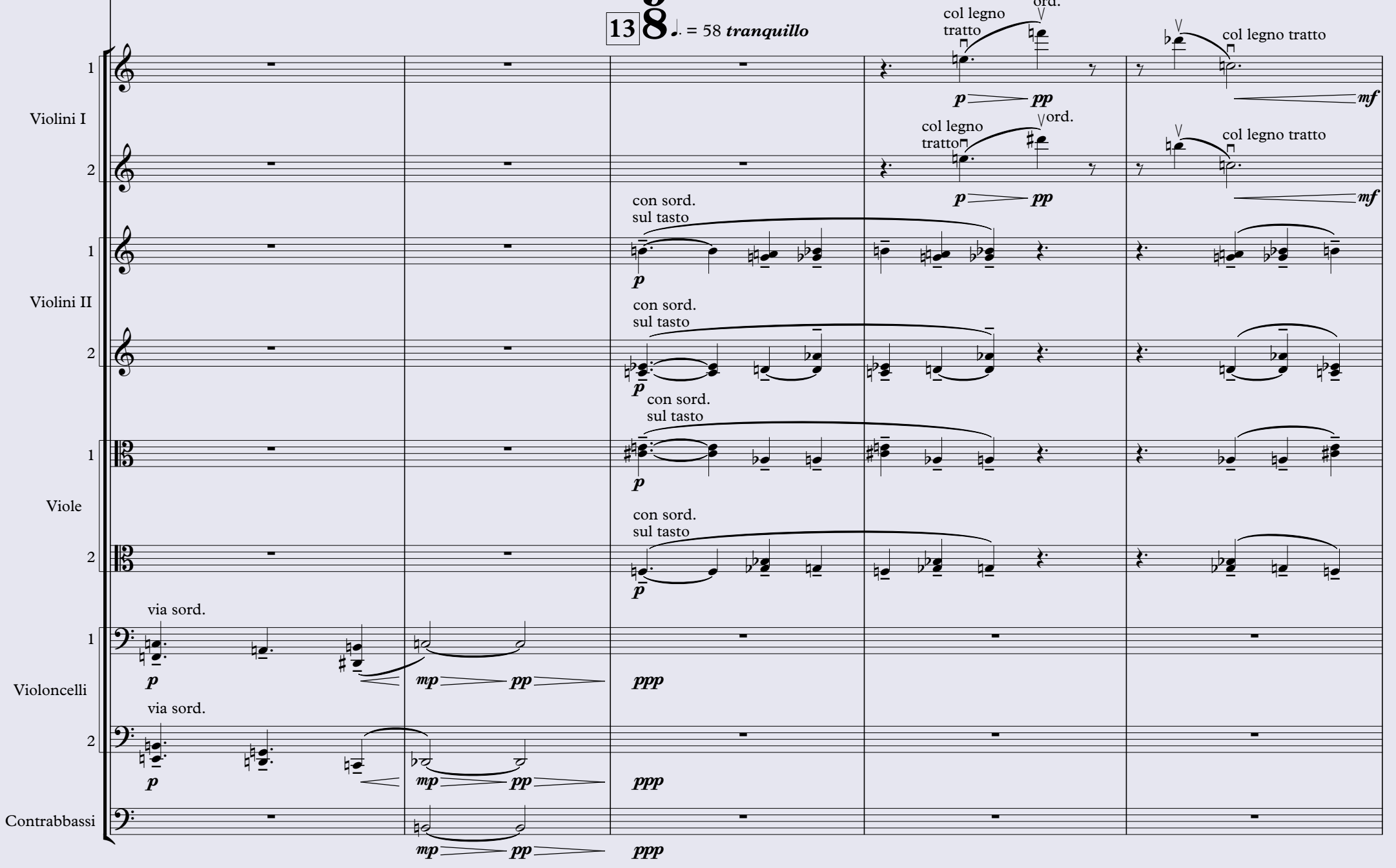



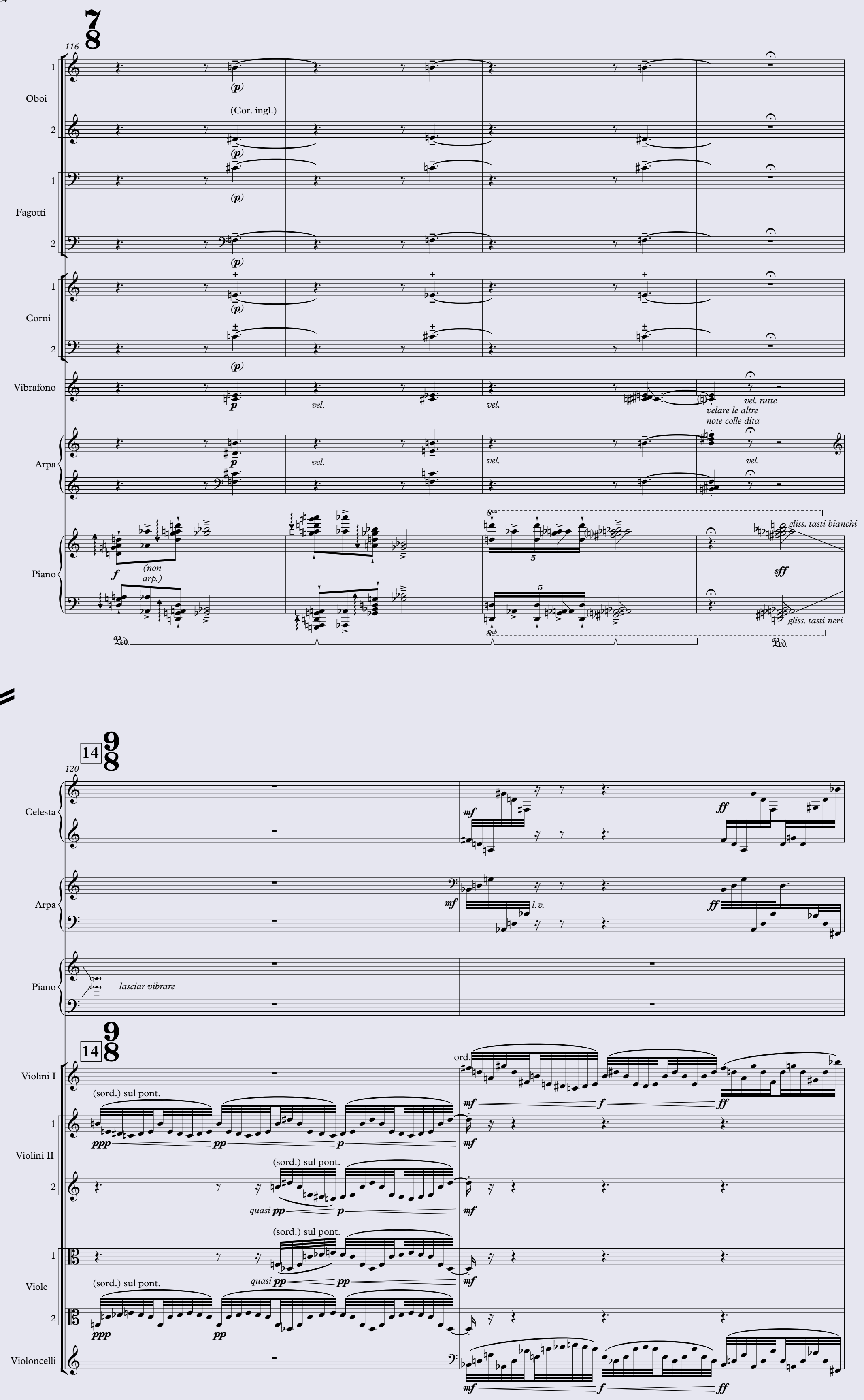


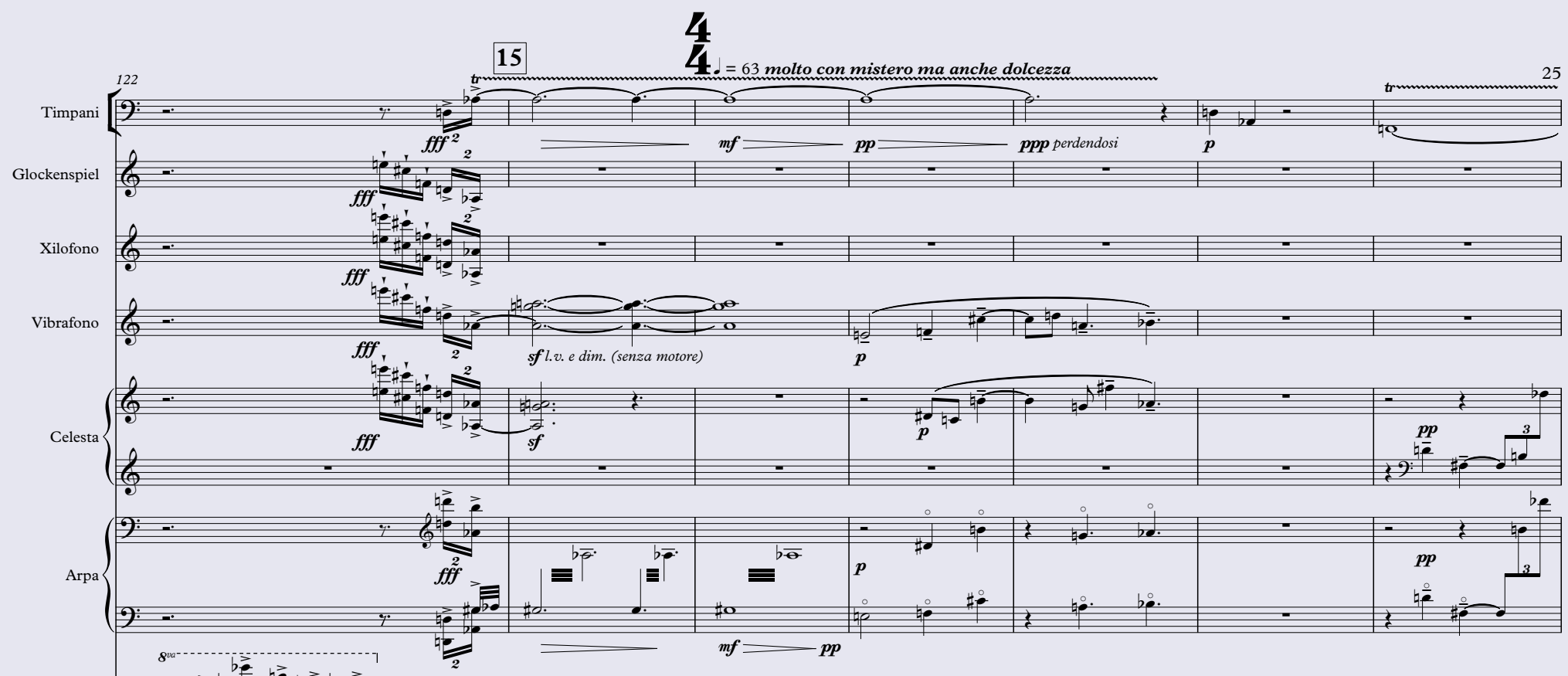

$\int(6+5)$

lasciar vibrare
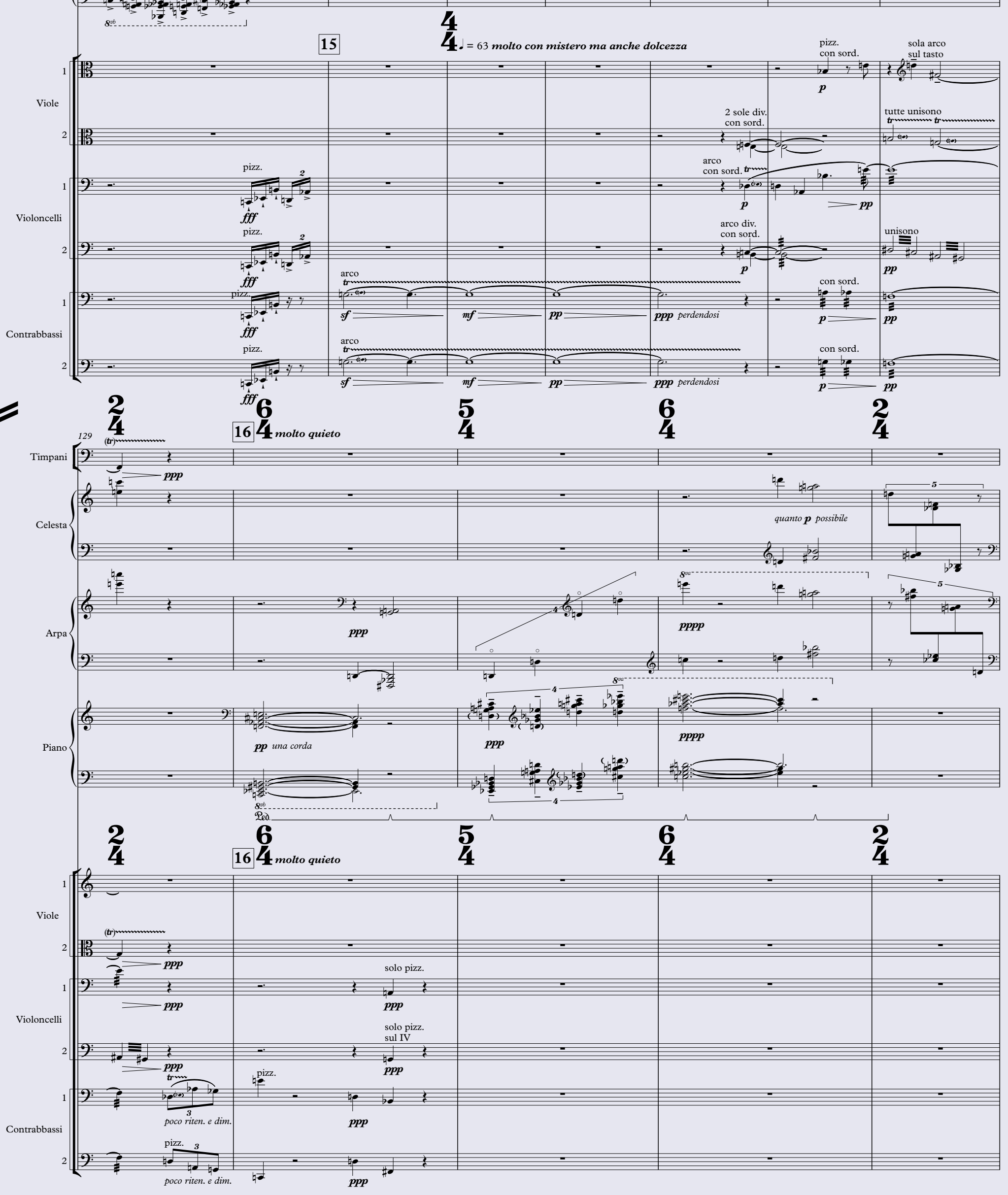


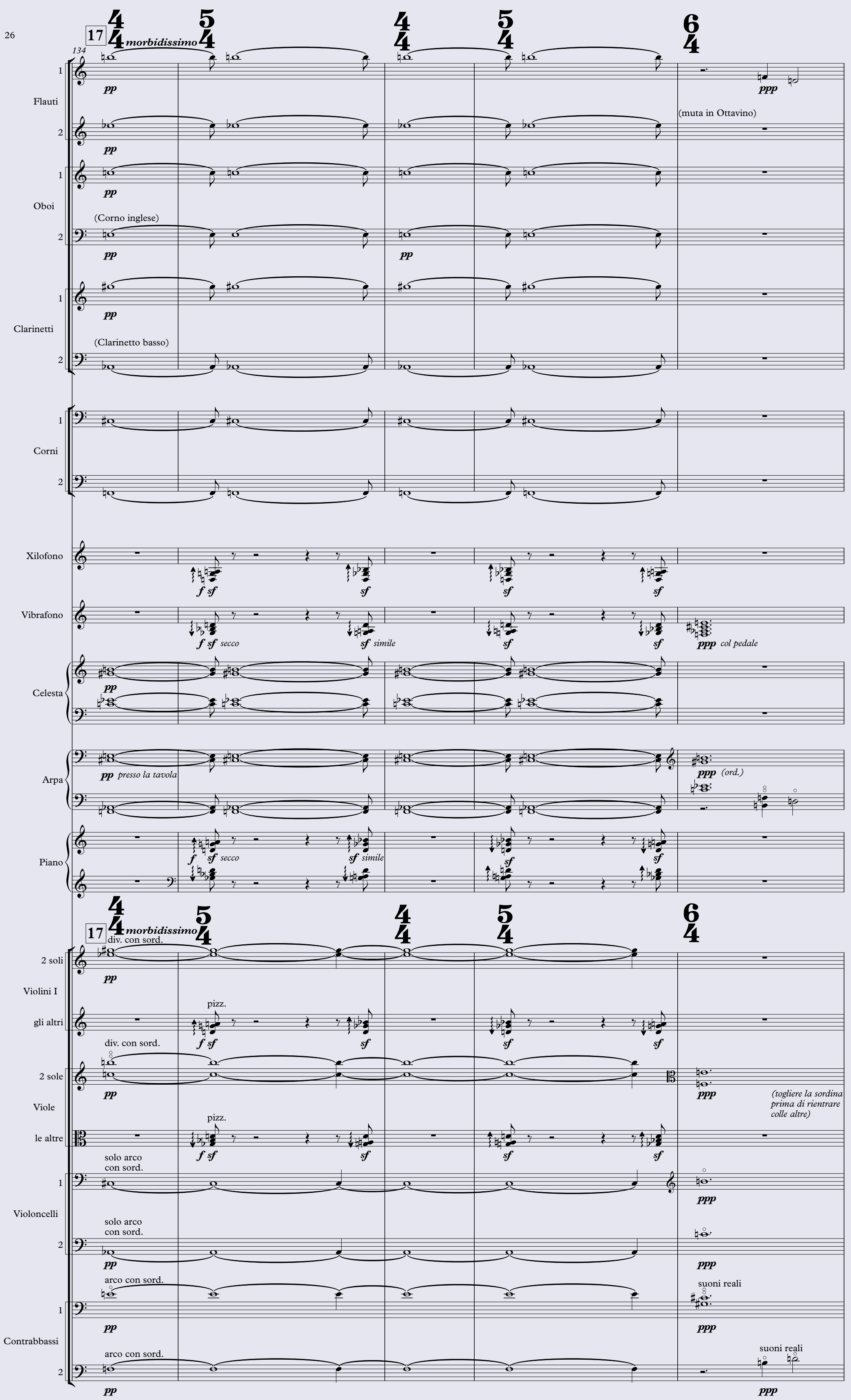



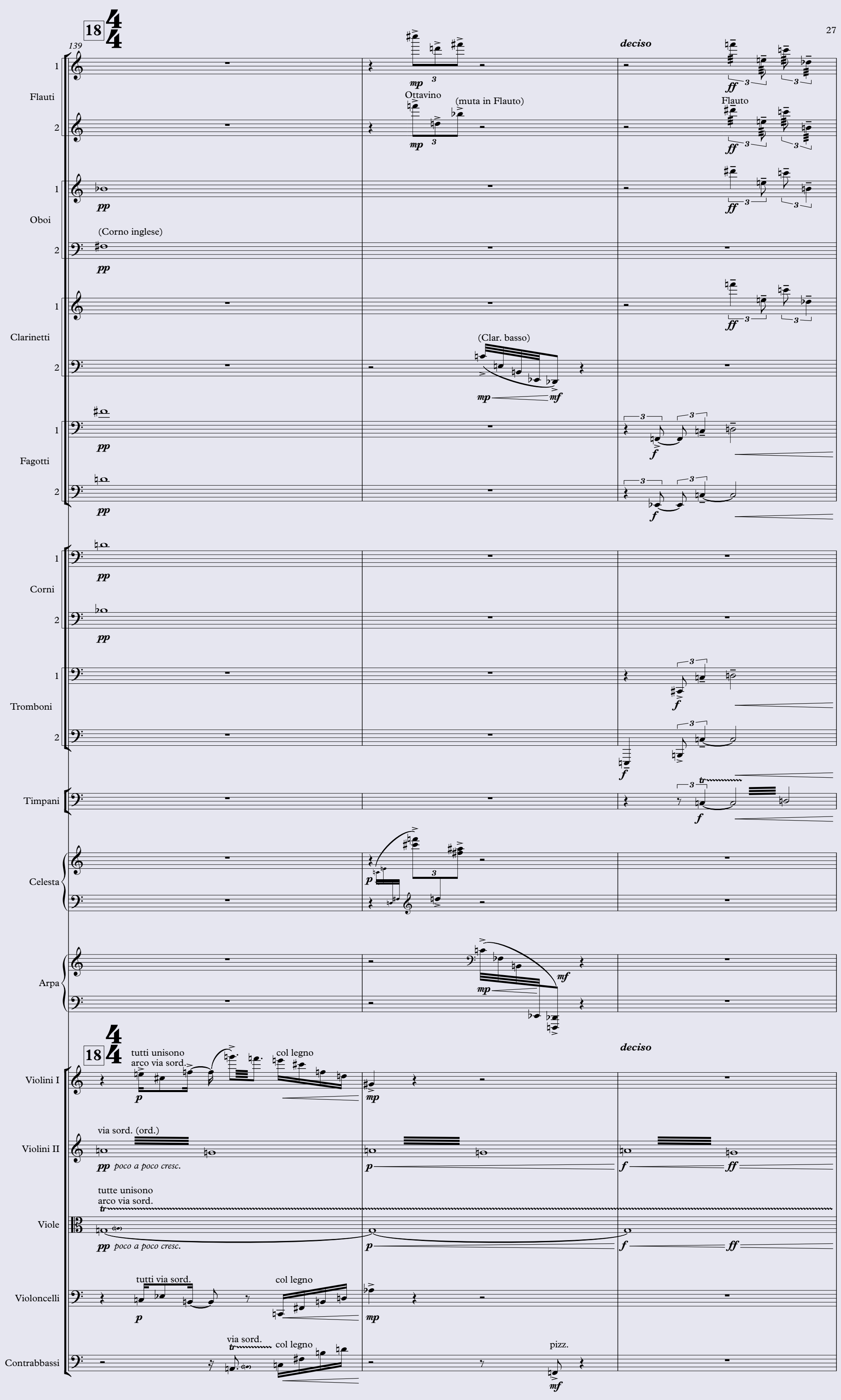


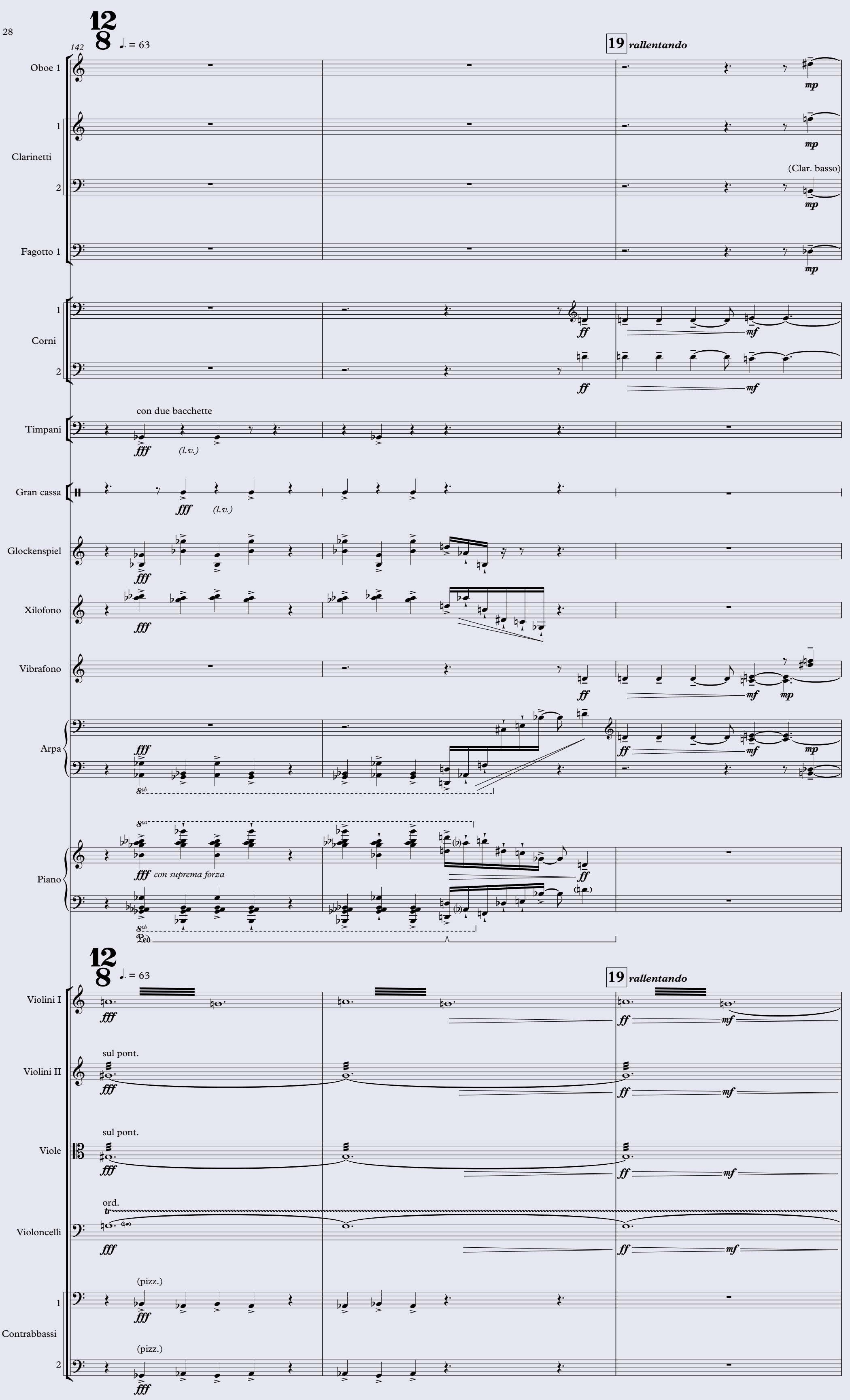


Revista del Departamento de Música - Grupo de investigación en Estudios musicales RICERCARE
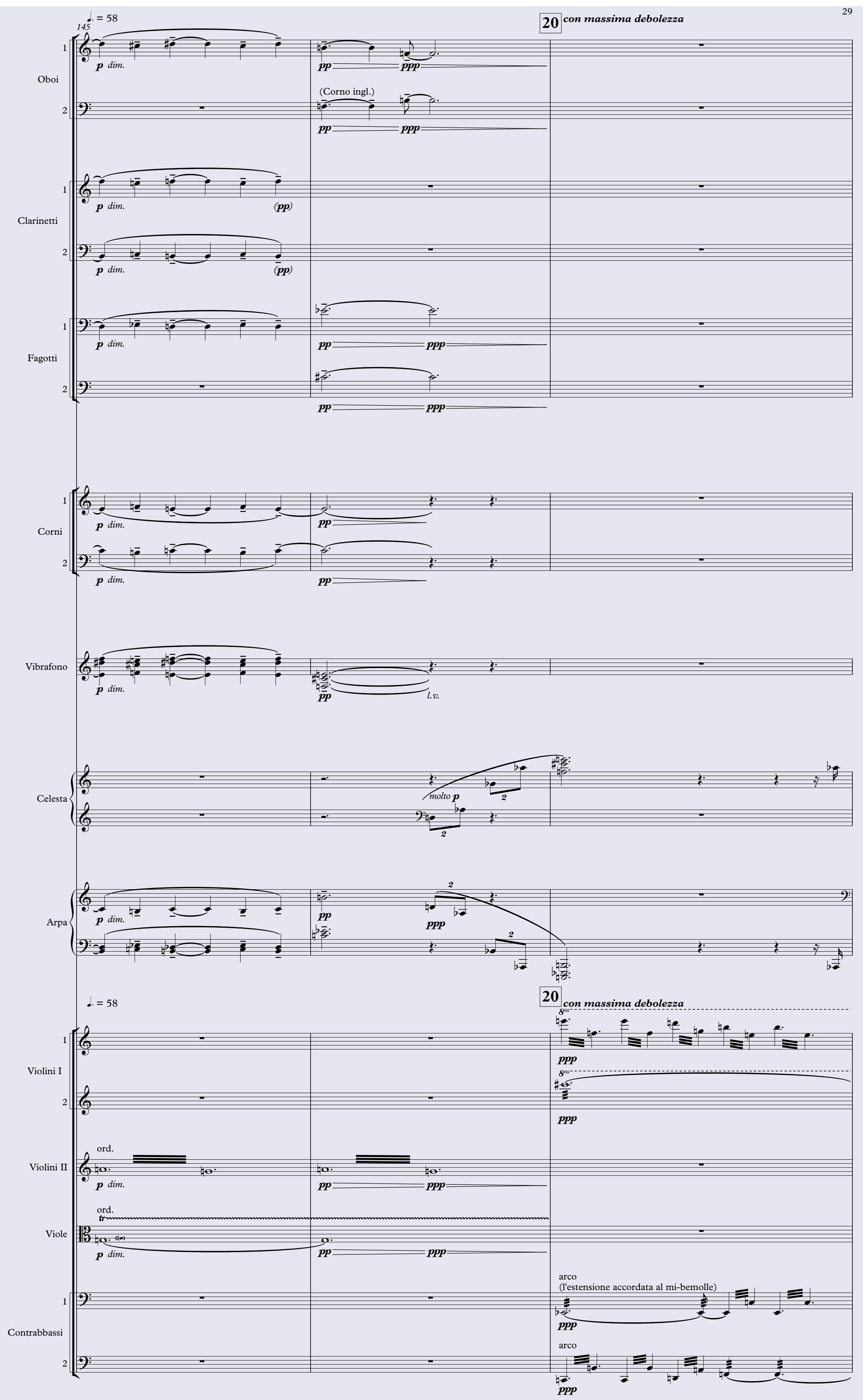

Núm. 14 (2021) 34 
Partitura Staring Wei Jie to Death

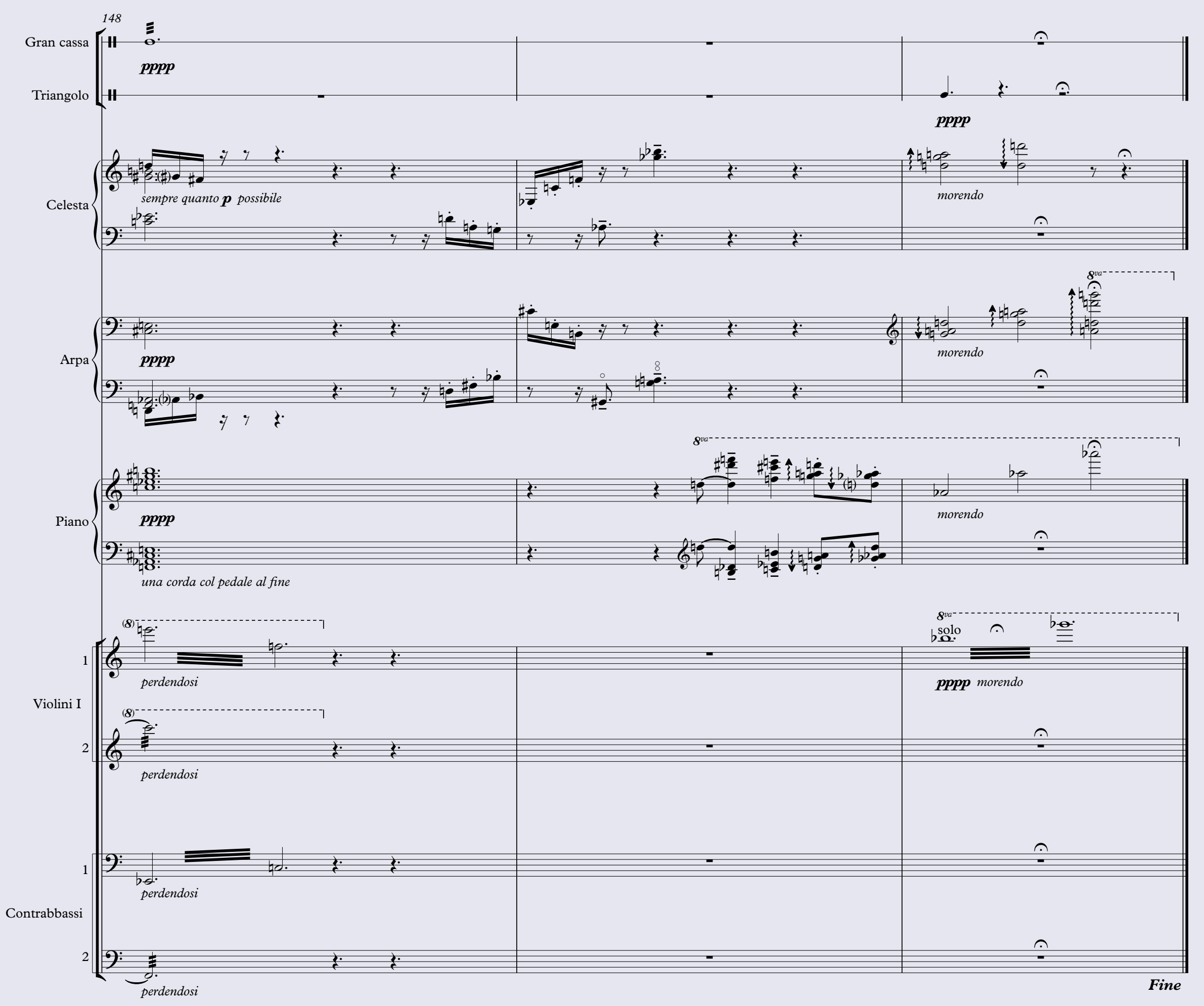

Paulo do Nascimento Brito 35 